Number 165 - July 2013

\title{
COALITION GOVERNMENTS, CABINET SIZE, AND THE COMMON POOL PROBLEM: EVIDENCE FROM THE GERMAN STATES
}

Thushyanthan Baskaran

Georg-August-Universität Göttingen 


\title{
Coalition governments, cabinet size, and the common pool problem: evidence from the German States
}

\author{
Thushyanthan Baskaran* \\ University of Goettingen \\ tbaskar@uni-goettingen.de
}

\begin{abstract}
The theoretical literature on common pool problems in fiscal policy suggests that government fragmentation increases public expenditures. In parliamentary regimes, the fragmentation hypothesis refers to (i) coalition governments and (ii) cabinet size. This paper explores the effect of coalition governments and cabinet size on public expenditures with panel data covering all 16 German States over the period 1975-2010. Identification is facilitated by the large within-variation in the incidence of coalition governments and the size of the cabinet in the German States. In addition, I exploit a feature of state electoral laws to construct a credible instrument for the likelihood of coalition governments.
\end{abstract}

Keywords: Government fragmentation, common pool problems, coalition government, cabinet size, public expenditures

JEL codes: D78, H61, H72

*Thushyanthan Baskaran, Department of Economics, University of Goettingen, Platz der Goettinger Sieben 3, 37073 Goettingen, Germany, Tel: +49(0)-551-395-156, Fax: +49(0)-551-397-417. 


\section{Introduction}

What determines the size of the public sector? The literature on this question can be classified along three lines. The traditional strand relates public expenditures to underlying economic trends. A famous contribution is Wagner's Law, according to which public sector size increases disproportionately with economic development (Wagner, 1911). This theory perceives the government as a benevolent planner who responds optimally to developments that are outside of its control. It is, however, contentious whether governments are truly benevolent. Perhaps to emphasize their skepticism toward the benevolence assumption, Brennan and Buchanan (1980) go as far as to model the government as a Leviathan who is only interested in revenue maximization. In the Leviathan-framework, the size of the public sector is explained by the extent to which the fiscal constitution is capable to limit the ability of the government to over-tax citizens. 1

In reality, governments are neither completely benevolent nor do they behave exclusively as Leviathans. The third strand of the literature focuses on the role of politics and applies neoclassical tools to model political decisions as the outcome of the interactions of selfinterested and rational agents who respond optimally to the incentives they face. Within this political economics literature, the seminal contributions of Weingast et al. (1981) and Shepsle and Weingast (1981) on common pool problems in policy making suggests that government fragmentation is one important determinant of public expenditures.

In countries with parliamentary regimes, the term government fragmentation refers to (i) the number of parties and (ii) the number of ministers represented in the government 2 The two variants of government fragmentation can result in common pool problems if the

\footnotetext{
${ }^{1}$ For example, it follows from the Leviathan model that public expenditures will decline in the degree of fiscal decentralization. The reason is that fiscal decentralization will result in tax competition, which will diminish the ability of the government to over-tax citizens.

2 The original model was developed for US-style legislatures and usually refers to the size of the legislature. Another variant of government fragmentation in countries with presidential regimes refers to situations with divided government, i. e. where the executive and the legislature are controlled by different parties (Alt and Lowry, 1994).
} 
benefits of public expenditures can be targeted to well-defined constituencies whereas the costs are shared equally by all members of the government. The reasoning is as follows. Each member of the government has to weigh the benefits of public expenditures against their cost. If expenditures can be targeted, the constituency of a government member fully internalizes the benefits. The cost associated with public expenditures is the political price that the government has to pay for either higher taxes or more debt. If the cost for targeted expenditures is shared among all members of the government, each individual member only pays a small fraction. Consequently, overall demand for public expenditures will increase in the number of government members. And given that "government members" can be defined either in terms of parties or in terms of ministers, the fragmentation hypothesis predicts that expenditures will increase in the number of parties represented in the government and the size of the cabinet.

A large empirical literature attempts to test how coalition governments and cabinet size relate to public expenditures. The relevant studies can be distinguished by whether they use cross-country or sub-national data. Notable cross-countrv studies are Roubini and Sachs (1989a.b). Edin and Ohlsson (1991). De Haan and Sturm (1997). Perotti and Kontopoulos (2002), Woo (2003), and Bawn and Rosenbluth (2006). While there are some conflicting result 3 , this strand of the literature tends to conclude that both coalition governments and large cabinets exacerbate the common pool problem and cause either more spending or higher deficits.

However, one problematic feature of the cross-country studies is that they have to cope with a large degree of heterogeneity. It is difficult to fully account for the cross-country heterogeneity by means of control variables. A recent literature attempts to address the heterogeneity problem by using data at the sub-national level. Ashworth and Heyndels (2005), for example, show that in Flemish municipalities, coalition governments and large

\footnotetext{
${ }^{3}$ For example, De Haan and Sturm (1997) find no evidence for the fragmentation hypothesis.
} 
cabinets are in general associated with higher spending. Le Maux et al. (2011) find for French Departments that the number of parties in the ruling coalition is positively related to social expenditures. Borge (2005) concludes for Norwegian municipalities that less fragmented local councils lead to smaller deficits.

While these studies use data at the local level, Schaltegger and Feld (2009) use data at the level of the Swiss Cantons. Compared to municipalities, the Swiss cantons have significant political autonomy and are responsible for a large share of total public expenditures. Schaltegger and Feld (2009) find that public spending increases in the size of the cabinet while the effect of coalition governments is ambiguous. One problematic feature of their study is, however, that over-time variation in their coalition and cabinet size variables is limited. The small within-variation in their data forces them to base their conclusions primarily on the variation between cantons. Consequently, there could remain unobserved factors that influence both public expenditures and government fragmentation simultaneously.

I study in this paper whether coalition governments and large cabinets cause larger public spending with panel data covering all 16 German States over the period 1975-2010 4 As the Swiss Cantons, the German States offer an excellent opportunity to investigate the effects of fragmented governments at a powerful and fiscally important tier of government. The German States have similar political and legal systems, a common history, and close linguistic and cultural ties. Because of the relative homogeneity of its states, the German federation can serve as a natural laboratory. But unlike the Swiss Cantons, the German States exhibit large within-variation in the incidence of coalition governments and the

\footnotetext{
${ }^{4}$ In contrast to Schaltegger and Feld $(2009)$, I focus on whether a state government is formed by a single party or by a coalition of parties, but not on the size of the coalition. The reason is that state governments in Germany are typically formed by either a single party or by a coalition of two parties. Coalitions with three parties are extremely rare and coalitions with more than three parties were never formed.
} 
number of cabinet ministers, allowing the identification of the public spending effects of coalition governments and large cabinets by means of fixed effects regressions.

To further account for possible endogeneity, I exploit a feature of the electoral laws in all states that relates vote shares to seats in state parliaments in a non-linear fashion to construct a compelling instrument for the likelihood of coalition governments. In a nutshell, every state has a so called "five-percent hurdle". Only parties that receive more than five percent of the votes are entitled to seats in parliament. Any seats to which parties with less than five percent of the votes would in principle be entitled to are distributed among the parties that actually manage to enter the state parliament. This feature of the electoral law has the consequence that the fewer parties enter the state parliament, the easier it is to form a single-party government for the biggest party because the probability of having more than $50 \%$ of the seats is inversely related to the number of parties in parliament. At the same time, the number of parties in parliament has no obvious direct effect on spending. Consequently, this variable can serve as a valid and strong instrument for coalition governments.

The link between coalition governments and public deficits in the German states has been previously analyzed by Jochimsen and Nuscheler (2011). As German States have no tax autonomy (see below), borrowing and expenditures are closely linked. However, since the fragmentation hypothesis is only one of manv hypotheses that Jochimsen and Nuscheler (2011) investigate, it is only cursorily explored. In particular, it is unclear whether their result that coalition governments spend more than single party governments is robust. In contrast, I focus exclusively on the fragmentation hypothesis which allows for a more thorough analysis. Indeed, my results with respect to the fiscal effects of coalition governments contradict the findings in Jochimsen and Nuscheler (2011).

The link between the structure of the cabinet and fiscal policy has been previously explored for Germany as well. A relevant contribution is Jochimsen and Thomasius (2012) 
who study how characteristics of the finance minister relate to deficits. Yet, the overall size of the cabinet is neglected in their paper. Further studies exploring the political economy of fiscal policy in the German States, albeit with a different focus than the fragmentation hypothesis, are Seitz (2000), Galli and Rossi (2002), and Pitlik et al. (2005).

\section{The fiscal and political landscape in the German States}

Germany consists of sixteen federal states: eleven West-German and five East-German (see Figure 1 for a map) 5 The fiscal constitution grants all states significant spending but only minuscule tax autonomy. Each of the states can borrow and spend according to its own discretion, while rates and bases for most taxes are the same throughout the federation. Variation in state level taxation only exists for some unimportant taxes.

The federal constitution defines a wide set of public goods which have to be provided by the sub-national tier. States are expected to finance all stages of education, cultural affairs, the police, and many other public goods 6 The policy areas for which the states are responsible make up more than half of public spending in the German federation. While there are some federal mandates defining minimum levels for the state public goods, states can in general decide autonomously on expenditures (Seitz, 2008). Figure 11 shows that the states use their expenditure autonomy extensively. The average real expenditures per capita during the 1975-20010 period in Berlin, Bremen, Hamburg, or the East-German states was almost twice as high as in Bavaria and Lower-Saxony. There is also signifi-

\footnotetext{
${ }^{5}$ The state of Berlin is somewhat of a hybrid because it was formed in 1991 by merging the western with the eastern part of the city. In the following, I treat Berlin as a West-German State.

${ }^{6}$ The sub-national tier consists of states and different types of localities. However, the localities are legally subordinate and accountable to the states (Kipke, 2000). In particular, the federal constitution defines local finances as part of state finances (Art. 106 Abs. 9 GG). All fiscal variables discussed in the following (notably state expenditures and revenues per capita) are consolidated between states and localities.
} 
cant amount of over-time variation in state spending as suggested by Figure 2, Average expenditures per capita in the West-German states increased until 1990, then spiked dramatically, presumably because of the need to fund the German unification. Thereafter, a slow decline in expenditures per capita can be observed in the West-German States until the outbreak of the financial crisis in late 2007. In East-Germany, expenditures increased until the mid-nineties, again presumably because of the need to modernize public infrastructure and delays in reducing the number of public employees in the aftermath of unification (Reichard, 2001). From the mid-nineties onward, however, expenditures per capita have been on a downward trajectory in East-Germany. By 2010, they had declined below the level of the West-German states.

Politically, the German States are parliamentary democracies. Each state has a unicameral parliament elected by its residents.7 Elections to the state parliament are governed by electoral laws that are, while not identical, very similar throughout the federation. Most importantly, all states have a so called "five-percent hurdle" that limits the number of parties that may enter parliament. This hurdle - introduced in order to avoid a repetition of the massive party fragmentation in the Reichstag during the Weimar Republic and the ensuing difficulties in forming a government with sufficient parliamentary support- implies that only parties which receive at least five percent of the votes will get seats in the parliament 8 This feature of the electoral system ensures that parties that are allowed to enter parliament receive a larger share of seats than would be warranted by the vote share, which

\footnotetext{
${ }^{7}$ Bavaria's parliament had a second chamber, the Senate, until 1999. The Senate was abolished through a popular referendum because it was essentially powerless.

${ }^{8}$ There are two exceptions. Parties with less than five percent may enter the state parliament in some states if some of their candidates win in their districts (the number of districts that have to be carried by the party to enter parliament through this rule varies between states). This exception is fairly irrelevant and has hitherto only applied to one party, the PDS, and only at the federal level. At the state level, the PDS either easily passed the five-percent hurdle (in the East-German states) or did not win any direct mandates (in the West-German states). There is also an exception for the party of the Danish minority (the SSW) in the state of Schleswig-Holstein. For this party, the five-percent hurdle is waived.
} 
makes it easier to form a government with majority support in parliament. I discuss the consequences of this feature of the electoral system in more detail in Section 6 .

In 1975 there were three major parties both at the federal level and in each of the eleven West-German States: the Christian Democratic Union (CDU), the Social Democratic Party of Germany (SPD), and the Free Democratic Party (FDP). In general, the CDU is perceived as culturally conservative (i. e. supporting "traditional" values) and moderately marketoriented. The SPD is moderately left-leaning on economic and moderately liberal on cultural issues. The FDP is culturally liberal and market-oriented with respect to its economic policies. By 2010 the number of mainstream parties in the now unified Germany had increased to five. In addition to the CDU, SPD, and FDP, the Green Party and a new left-wing party (Party of Democratic Socialism (PDS), later renamed Die Linke) entered the political scene.

The Green Party started to receive significant vote shares at the end of the seventies by focusing on environmental and peace issues (recall that the cold war was still ongoing at the time). It is moderately left-leaning on economic policies. Yet, its main support base are civil servants rather than the working class. With respect to cultural issues, it is generally perceived as very liberal.

By the mid-eighties and early nineties, the Green Party had entered most state parliaments and was even part of some state governments as a coalition partner of the SPD. This change in the German party system is reflected in Panel (a) of Figure 39 According to

\footnotetext{
${ }^{9}$ There is some ambiguity in determining the correct coding of the number of parties in parliament and other political variables in election years. The type of government, the size of the cabinet, and the number of parties in parliament typically change after an election. The election dates, however, differ both between and within states. I apply the following rule: if an election in year t takes place after July 1th, I code the political variables for year $\mathrm{t}$ according to the situation early in the year (since the old administration has governed more than half of the year). If the election takes place before July 1th, I code the political variables according to the situation late in the year.

For example, assume that the SPD has received more than $50 \%$ of the seats in an election in state i in year $t$, so the next administration will be formed by the SPD. Assume furthermore that the current administration is a CDU-FDP coalition. If the election took place on or after July 1st, I code the coalition variable as 1 . If the election took place before July 1 th, I code the coalition variable as 0 . I apply the same
} 
this panel, the median number of parties in West-German state parliaments was three until the mid-eighties. Then the median number jumps to four and remains there until the end of the sample period, where it increases to five. The evolution of the average number of parties in state parliaments, too, reflects the rise of the Green Party. This number remains around three until the mid-eighties and then increases fairly steeply to four and remains there until 2005. At the end of the sample period, the average number had increased to five.

The other addition to the German party system during the 1975-2010 period was the Party of Democratic Socialism (PDS). Unlike the Green Party, the PDS did not represent a new political movement. Rather, it was the former ruling party of the German Democratic Republic (GDR) - the Socialist Unity Party (SED) - that had reconstituted itself as the PDS after the demise of the GDR in 1990. In 2007, the PDS merged with a West-German Party called WASG and reconstituted itself as Die Linke. For simplicity, I will refer for the remainder of this paper to Die Linke as PDS.

The importance of the PDS in East-Germany is implicitly reflected in Panel (b) of Figure 3. According to this panel, the median number of parties in the East-German state parliaments was five in the first half of the nineties. In the mid-nineties, the median number dropped to three and remained there until the very end of the sample period, as both the FDP and the Green Party found it increasingly difficult to collect sufficient votes to enter parliament. The three parties that remained relevant in the East-German party system were the CDU, the SPD, and the PDS. Only after 2005, things begun to change with respect to both the average and median number of parties in parliament increasing to five in 2010.

Figure 4 shows the average number of parties in the East- and West-German state parliaments. This figure suggests that states differ in their openness toward smaller parties.

rule for the cabinet size variable, the parties in parliament variable, and the number of seats in parliament variable. 
In Bavaria, the average number of parties represented in parliament was around three. In states like Baden-Wuerttemberg, Berlin, and Bremen, the average number of parties was over four during the 1975-2010 period.

The CDU and SPD are generally referred to as the "big" parties during the 1975-2010 period because they typically received between $30 \%$ to $40 \%$ of the votes in each election 10 The FDP and the Green Party are referred to as the "small" parties. The PDS is difficult to classify along this dimension. In East-Germany, it was not uncommon for the PDS to receive around $25 \%$ of the votes during the $1975-2005$ period. It may therefore be legitimately classified as a big party in the eastern part of Germany. In West-Germany, however, the PDS never managed to get more than five percent of the votes until the very end of the sample period (with the exception of Berlin).

The state government requires a majority in the parliament to govern effectively. Minority governments are therefore very rare and generally short-lived 11 As a rule, each of the two big parties forms a single-party government if it receives more than $50 \%$ of the seats. There have been some exceptions to this rule, but not in recent times. That is, a big party with an absolute majority has sometimes invited a small party to join a coalition, but the small parties have always declined to do so during the 1975-2005 period. One example is Hesse after the elections of 2003 where the CDU gained an absolute majority but nonetheless invited the FDP to join the cabinet. The FDP declined.

\footnotetext{
${ }^{10} \mathrm{By}$ now, this characterization is probably too simple because the Green Party has in some states, most notably in Baden-Wuerttemberg, over-taken the SPD in terms of votes. Nevertheless, the general perception is that the SPD is still the biggest left-wing party.

${ }^{11}$ Most minority governments are essentially caretaker governments that last only a few months before new elections can be held. The only meaningful exceptions were the SPD-Green Party government in Saxony-Anhalt during 1994-1998 and the sole SPD government in Saxony-Anhalt during 1998-2002. These two governments had the implicit support of the PDS, even though it was not formally part of the government. It might be argued that the sole SPD government in Saxony-Anhalt was in reality a coalition with the PDS in all but name. Moreover, there is theoretical work which suggests that in situations with minority governments. the opposition might plav a decisive role for fiscal outcomes (Falco-Gimeno and Jurado, 2011). However, (unreported) regression results with a redefined coalition variable that codes Saxony-Anhalt as having a coalition government during the 1998-2002 period are very similar to those reported in the paper.
} 
If one of the big parties has less than $50 \%$ of the votes in parliament, negotiations to form a coalition government are held. The need to hold a new election because of the inability to form a government almost never arises as the parties represented in parliament can almost always agree on some type of coalition.12 A big party typically prefers to form a coalition with a small party if they together can achieve a majority in parliament. If this should not be possible, the two big parties usually form a coalition 13 Only in four cases, coalition governments consisting of three parties have been formed (one big and two small parties). Coalition governments consisting of more than three parties were never formed.

In principle, every party can form a government with any other party. In practice, only certain types of coalition governments have been formed in the 1975-2010 period. Figure 5 reports the relative frequencies of different types of (coalition and single-party) governments. During the sample period, neither the CDU nor the FDP collaborated with the PDS. In West-Germany, the SPD and the Green Party also refused to cooperate with the PDS. (Berlin, however, is again an exception: the SPD did form a government with the PDS there). Figure 5 also reveals some additional ideological patterns in coalition formation. The CDU tends to form coalitions with the FDP whereas the SPD tends to form coalitions with the Green Party, even though some coalitions between the SPD and the FDP also took place. Only at the very end of the sample period, these patterns begun to change slightly. In Hamburg, a coalition governments between the CDU and the Green Party was formed in 2008, but it was only short-lived. Similarly, a CDU-Green Party-FDP government was formed in 2010 in Saarland, but was soon dissolved as well.

Around half of all state governments in the 1975-2010 period have been formed by a single party. The CDU has formed more single party governments than the SPD, but the SPD has also managed to form a significant number of single party governments. Panel (a)

\footnotetext{
${ }^{12}$ However, Hesse after the election of 2008 is a recent example where new elections had to be called because of the inability of the parties to form a stable government.

${ }^{13}$ In contrast to recent theoretical work on coalition formation, e. g. Bandyopadhyay and Oak (2008) and Tridimas (2011), coalition formation in Germany is thus straightforward.
} 
in Figure [6] shows the number of state governments in West-Germany ruled by coalition governments for each year between 1975-2010. Five of the eleven western states were ruled by coalition governments in 1975. By 1980, their number had fallen to two and in 1985 even declined to one. Thereafter, there was a continuous increase in the number of coalition governments. In 2003, eight states were governed by coalition governments. In 2005, the number still stood at seven. In 2010, it had increased to ten. Panel (b) reports the number of coalition governments during the 1991-2010 period in East-Germany. The eastern states start out with four coalition governments. Their number declines to two around 2000. By 2010, however, their number had once again risen to five.

Figure 7 reports the relative frequency of coalition governments in each of the German States. It reveals that all but one state have experienced both single-party and coalition governments during the sample period. The only exception is Mecklenburg-Western Pomerania, which was consistently ruled by a shifting set of coalition governments. On the other hand, single-party and coalition governments were almost equally common in States like North Rhine-Westphalia and Bremen. Overall, both Figure 6 and 7 confirm that there is a significant amount of between and within-variation in the incidence of coalition governments.

Once agreement on a government with a legislative majority has been reached between the parties involved, the cabinet is formed. The process starts with the election of a state prime minister by the state parliament. The state prime minister then appoints his cabinet. In some states the cabinet has to be approved by the state parliament, but this is only a formality. While the state prime minister is in theory free to choose the cabinet members and the scope of the individual ministries, the parties involved in the government have significant influence on the structure of the cabinet and the identity of the ministers. There are some core ministries which exist in all states, for example the finance or the interior ministry. The number and scope of the other ministries varies both 
between and within states. For example, there are separate health and social ministries in some state-year pairs. In others, these two policy areas are covered by a single ministry.

Panel (a) of Figure 8 reports the evolution of the average cabinet size for West-German. This panel shows that in 1975, the average cabinet had around 10 members. Average cabinet size steadily increased to more than 12 in 1990. From 1995 onward, the average cabinet size started to decline again and reached around 10 in 2010. In East-Germany, the average cabinet size was slightly larger than 10 during the 1990s. From 2000 onward, average cabinet size was slightly less than 10 .

Figure 9 reports the distribution of the average cabinet size in each of the German States during the 1975-2010 period 14 This figure suggests that there are significant differences between the German States. Average cabinet size in Berlin was almost 12 whereas Saarland had an average cabinet size of around 8. The distribution of the average cabinet size was between 9 and 11 in East-Germany. Overall, the descriptive statistics reported in Figure 8 and 9 suggests that there is a significant degree of variation in cabinet sizes, in particular within states.

\section{Methodology and empirical model}

The hypothesis I investigate is whether coalition governments and governments with large cabinets spend more than single-party or small cabinet governments. Panel (a) of Figure 10 compares average real expenditures per capita in coalition and single-party governments during the 1975-2010 period. I deflate public expenditures and all other nominal variables with the federation-wide CPI. This panel shows that coalition governments spend on aver-

\footnotetext{
${ }^{14} \mathrm{My}$ primary data source is Schnapp (2006). The data were collected as part of a research project of the German Science Foundation. For most states, the data are available until 2005. I collected data for the remaining years (2005-2010) and completed missing data in the original source using information supplied by different state governments or state parliaments. Note that I also corrected a few minor errors in the original files forwarded by the state governments to Schnapp (2006).
} 
age about 590 Euros more than single-party governments. Panel (b) reports the averages for each of the cabinet sizes that German states exhibited during the 1975-2010 period.

There appears to be a positive relationship between average cabinet size and public expenditures. Note that that the number of very large cabinets is limited, leading to sampling variability. For example, the high expenditures per capita ratio found for a cabinet size of 16 is exclusively driven by one particular cabinet in Berlin.

The question is whether the positive bivariate relationships between public expenditures, coalition governments, and cabinet size continue to prevail in a quantitative analysis. A model to formally test the fragmentation hypothesis should relate the increase in public expenditures to the two types of government fragmentation and other potential determinants of expenditures. It can be specified as follows:

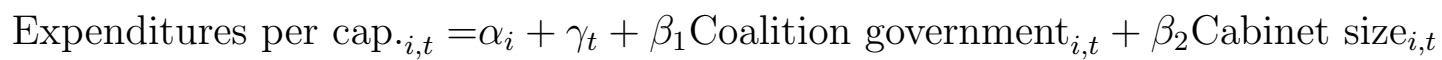

$$
+\gamma \text { Expenditures per cap } \cdot_{i, t-1}+\delta \mathbf{x}+\epsilon_{i} \text {. }
$$

This model states that real public expenditures per capita are a function of whether the government consists of a coalition of parties or is formed by a single party, the size of the cabinet, and the level of expenditures in the previous period. In addition, a set of variables $\mathbf{x}$ are included as potential determinants of public expenditures. Finally, $\alpha_{i}$ is a dummy variable that is 1 for state $i$ and $\gamma_{t}$ is a year fixed effect.

The following variables are used as control variables: Revenues per capita, dummies indicating whether the government has a left or right ideology, the state unemployment rate, real GDP per capita, the share of the young $(\leq 15$ years) and old $(\geq 65)$ in the state population, a state election year dummy, and the number of seats in the parliament (see Table A.4 for sources and specific definitions). Most of these variables are straightforward 
determinants of public expenditures and presumably correlated with the structure of the government. A few require additional explanation.

First, revenues per capita are included to control for available fiscal resources. Note that this variable is essentially exogenous from the perspective of the states. Rates cannot be changed by the states for the most important taxes and intergovernmental transfers are distributed according to predetermined laws.

Second, ideological factors are likely to influence public expenditures. Because of multicollinearity with the coalition dummy variable, I cannot include separate dummies capturing the ideology of each single or coalition government. I therefore aggregate different types of government and classify then as having either a left or right ideology. More specifically, I define a state government as having a left ideology if it is formed either by the SPD alone, by a SPD-Green Party coalition, or by a SPD-PDS coalition. Similarly, a state government is assumed to have a right ideology if it is formed by the CDU alone or by a CDU-FDP coalition. The reference category are coalitions with at least one left and one right-wing party (CDU-SPD, SPD-Green Party-FDP, SPD-FDP, CDU-Green Party, and CDU-Green Party-FDP).

Finally, the state election year dummy is included to control for political business cycle effects. It is 1 in the year in which the election takes place, irrespective of whether the election takes place early or late in the year.

It must determined what estimation method to use for estimating Equation 1. An obvious choice is OLS. However, OLS might result in inconsistent estimates for two reason. The first reason is that Model 1 is a dynamic panel data model with cross-section fixed effects. Estimating such a model with OLS results in the so called Nickell bias (Nickell, 1981) 15 Yet, the Nickell-bias approaches 0 with T. Judson and Owen (1999) show that when $T=30$, the bias of OLS can be effectively ignored, especially when interest is

\footnotetext{
${ }^{15}$ Estimating Model 1 with OLS is equivalent to within-transforming the dependent and control variables and then using OLS to estimate a model without state fixed effects. However, the within-transformed
} 
not centered around the estimate for the lagged dependent variable. My strategy to deal with the Nickell bias is therefore to use OLS estimator and to rely on the large-T properties of the dataset, which runs from 1975 to 2010 and consequently covers 36 years. To check the robustness of this strategy, however, I also report in the Appendix estimates for Model 1 obtained with proper dynamic panel data estimators, notably the Bias Corrected LSDV estimator (Bruno, 2005), the Arellano-Bond Difference-GMM estimator and the Blundell-Bond System-GMM estimators, and one variant of the Anderson-Hsiao estimator (Roodman, 2008a).

The second reason why OLS might be biased is because of omitted variables: despite the use of a large list of control variables and time and state fixed effects, there may remain unobservable factors that affect both public expenditures and electoral outcomes and through them the likelihood of coalition governments. To account for this possibility, I will also report instrumental variables regressions, using the number of parties in parliament as instrument for the likelihood that a coalition government will be formed. Discussion on the strength and validity of this instrument is provided further below.

A potential reverse causality problem exists for the cabinet size variable. It is possible that governments increase the number of cabinet ministers if they intend to spend more. Unfortunately, it is difficult to construct a compelling instrument for this variable. The size and composition of the cabinet size is determined by the parties involved in the government in a discretionary way and there is no institutional mechanism that could induce quasirandom over-time variation in cabinet size. This problem is common to studies that use data at some higher level of government, notably at the state or federal tier because these tiers of government have typically the political and legal power to determine their institutional structure at their own discretion. 16

lagged dependent variable will be correlated with the within-transformed error term, leading to biased estimates.

${ }^{16}$ In contrast, many studies at the municipality level can rely on quasi-exogenous changes in institutional structures that are induced by regulations imposed by some higher tier of government. Pettersson-Lidbom 
However, it is reasonable in the context of the German States to assume that the overtime variation in cabinet size is not systematically influenced by planned changes in public expenditures. Anecdotal evidence suggests that state cabinets are primarily formed in view of political considerations. In particular, different wings of the parties that form the government have to be represented in the cabinet. For example, there is a more leftist and a more conservative wing in the SPD, and both wings are usually accommodated in some way in cabinets with SPD participation. Since many states are composed of different historical regions, geographical factors are important as well. For example, the state of Bavaria is divided in two parts, Bavaria proper and Franconia, and both have to be sufficiently represented in any CSU-led Bavarian cabinet. Consequently, political considerations are likely to trump attempts to structure the cabinet in view of expected public spending trajectories.

\section{Baseline results}

Baseline regressions of Equation 1 are reported in Table 1. The dependent variable in all models is real expenditures per capita. Standard errors for hypothesis tests are reported in Table 1 in parentheses. They are robust to heteroscedasticity and first-order autocorrelation (since the autocorrelation test: 17 reported in Table 1 are generally rejected) 18 An alternative approach to control for autocorrelation is to use clustered standard errors.

(2012) and Egger and Koethenbuerger (2010), for example, use population thresholds for municipal legislature sizes to implement regression discontinuity designs.

${ }^{17}$ I test for first-order autocorrelation with a procedure used by Devereux et al. (2008). This procedure works as follows. First, the initial model is estimated. Then the residuals are calculated. Finally, the lagged residuals are included in the initial model as an additional control variable. If the lagged residuals are significant and positive, I conclude that there is positive autocorrelation. If they are negative and significant, I conclude that there is negative autocorrelation. The bottom of the regression tables always include the p-value of the hypothesis tests for the lagged error terms (in the row labeled AR(1) test).

${ }^{18}$ To account for autocorrelation, I use a kernel-based approach implemented in the ivreg2-command for Stata. I rely on the Bartlett-kernel with a bandwidth of 2, which is equivalent to Newey-West standard errors (Baum, 2005). 
However, clustered standard errors are known to be unreliable if the number of clusters is small (Nichols and Schaffer, 2007). Cameron et al. (2008) develop a wild-bootstrap procedure to obtain reliable standard errors in such situations. I therefore report p-values based on the wild bootstrap procedure in brackets below the coefficient estimates.

According to Table 1, the coefficient estimate for the coalition dummy is consistently insignificant and numerically small. The coefficient estimate varies between -3 and 7 Euros. Since average per capita expenditures in the German States was around 4750 Euros during the sample period, these estimates suggest a negligible effect of coalition governments on spending.

On the other hand, the estimates for cabinet size are consistently positive. They are statistically significant according to hypothesis tests based on heteroscedasticity and autocorrelation-robust standard errors (or almost significant according to wild-bootstrap p-values) once control variables are added (Model IV). An expansion of the cabinet by one member only results in an increase in per-capita expenditures by around 10 to 15 Euros. While statistically significant in Model IV, the estimates do not indicate a particularly large economic effect. An increase of the cabinet size by one member increases expenditures by less than $1 \%$ of average expenditures per capita during the sample period.

The remaining control variables mostly perform as expected. Higher revenues lead to more expenditures. The share of under 15 year olds is positively related to expenditures as well, which presumably reflects the fact that compulsory primary and secondary public education is funded by the states in Germany. The election dummy, too, is significantly positive, which provides evidence for the existence of political business cycles. On the other hand, the estimates for macroeconomic variables (the unemployment rate and GDP per capita) and government ideology (the left and right dummies) are insignificant. 


\section{$5 \quad$ Expenditure categories}

One concern with the previous set of estimates is that they were only concerned with total expenditures per capita. It is, however, possible that while e.g. coalition governments have no effect on overall spending, they affect spending for individual tasks. For example, coalition governments might spend more on social services while less on infrastructure. While aggregate spending will remain constant in this case, coalitions would nonetheless impact fiscal policy by affecting the composition of public expenditures. Similarly, the relatively small effects of cabinet size on aggregate expenditures might mask larger but heterogeneous effects for individual spending items.

To explore this issue, I relate net expenditures on five different categories to coalition and cabinet size variables. I consider spending on (i) education, (ii) social services, (iii) health, (iv) public safety, and (v) infrastructure. Note that the data on the spending categories are based on a slightly different statistical definition than aggregate expenditures (specific transfers from other parts of the public sector are netted out, hence net expenditures).

The results are collected in Table 2, For coalition governments, we find no evidence for distinct effects on individual spending items. The estimated coefficients are numerically small and usually insignificant. Only for health expenditures, the coefficient is negative and significant according to the robust standard errors (and almost significant according to wild-bootstrap standard errors). In any case, coalition governments spend at most only 5 Euros less than single-party governments on health.

I obtain more heterogeneous results for cabinet size. Larger cabinets spend more for health, public safety, and infrastructure, but not for social services and education. The differences are minor, however. More specifically, an increase in cabinet size by one seat increases expenditures for health by less than $2 \%$ for, for public safety by less than $1 \%$, and for infrastructure by around $1.5 \%$ of average expenditures per capita. 
Overall, the estimates for coalition governments and cabinet size are consistent with the baseline findings. For all expenditure categories, spending by coalition governments is similar (or possibly even lower in case of health expenditures) than spending by singleparty governments. Similarly, cabinet size has a moderately positive or neutral effect on each of the individual expenditure categories.

\section{Instrumental variables regressions}

Another concern with the baseline estimates is the endogeneity of the coalition dummy. In particular, unobserved omitted variables influencing both the likelihood of coalition governments and public expenditures within states might bias the results. The robustness of the previous estimates can be checked through the use of an instrument for the likelihood that a coalition government will be formed.

The instrument I rely on is the number of parties in the state parliament. The fewer parties are represented in the state parliament, the easier it becomes to form a single-party government. The reason for this is the non-linearity in the formula that relates vote shares to seats in parliament at the five-percent hurdle. Parties with five percent of the votes receive about five percent of the seats in parliament. Parties with slightly less than five percent receive no seats at all. Since the number of seats in the parliament is essentially fixed, the seats that would have accrued to the party that failed to enter parliament if there were no five-percent hurdle are given to the parties that actually are represented in parliament according to their relative vote shares 19

For example, consider a parliament with 100 seats. To ensure a stable government, the parties involved must at least have 51 votes. Assume that there are four parties: A, B, C,

\footnotetext{
${ }^{19}$ States use different formulas to map votes into seats (Hare-Niemeyer, d'Hondt, and Sainte-Laguë). Yet, they all strive to achieve proportionality between vote shares and seats in parliament of parties with more than five percent of the votes.
} 
and D. Party A has received in the election a vote share of $47 \%$ and party B a vote share of $44 \%$. Now, if Party $\mathrm{C}$ and $\mathrm{D}$ each have $4.5 \%$ of the votes, they will not be allowed to enter parliament. Party A then receives $(47 / 91) \% \times 100=52$ of the seats wheras party B receives $(44 / 91) \% \times 100=48$. Party A can therefore form a stable single-party government.

Now consider a situation where party $\mathrm{C}$ receives in the election $5 \%$ of the votes whereas Party D receives $4 \%$. Then, party $\mathrm{C}$ is allowed to enter parliament. Party A then receives $47 / 96 \%=49$ of the seats, party B $44 / 96 \%=46$ and party $\mathrm{C} 5 / 96 \%=5$. Thus, party A wil not be able to form a single-party government.

As this example illustrates, the number of parties in parliament will affect the ability of the CDU or the SPD to form a single-party government. The more parties can overcome the five-percent hurdle, the higher the probability that a coalition government will be formed. Therefore, the number of parties in parliament should be a strong instrument.

What about instrument validity? To be valid, the instrument should fulfill the exclusion and conditional independence restrictions. Both the exclusion and the conditional independence restriction are required to ensure that the instrument is not correlated with the error term, conditional on the control variables. The exclusion restriction implies in the current context that the the number of parties in the state parliament has only an effect on expenditures through its effect on the likelihood that a coalition government will be formed. If this assumption is valid, the instrument can be excluded from the second stage regression. Validity of the independence assumption requires that the number of parties in parliament is not correlated with omitted variables that belong in the second stage regression.

There is no reason why the number of parties in parliament should affect public expenditures directly, i. e. the exclusion restriction should hold. First, since the opposition has no authority over fiscal policy, it does not matter of how many parties it is composed of. Consequently, the fragmentation of the state parliament is irrelevant for public spending 
apart from its effect on the likelihood of coalition governments. Second, the number of seats in parliament is essentially fixed, and thus more parties in parliament will not result in higher expenditures because of the need to fund more representatives (see below for some details on this).

The conditional independence might be perceived as more problematic in the current context. It is possible to argue that voters with idiosyncratic but unobservable preferences regarding public expenditures might at the same time prefer more or less homogeneous parliaments. This may result in a correlation between the error term and the instrument in the second stage regression.

How likely is such a scenario? First, it demands that any unobserved preferences are state-specific and time-varying (given that the model I estimate controls for state and year fixed effects). Given the relative homogeneity of the German electorate, such state-specific developments are probably unimportant, and should to the extent that they exist be picked up by the time-varying variables that are included in the model. Second, such a scenario would demand a great deal of coordination between voters with different ideological persuasions, i. e. between the left and the right of the political spectrum. For example, assume that a large fraction of FDP supporters decides in some election to vote for the CDU in order to make a coalition government less likely. There will be some FDP supporters that always vote for the FDP, even if it has no chance of entering the parliament. But if the FDP does not enter the parliament, then these votes are lost for the right block. In such a situation, it is typically not rational for the supporters of the Green Party, the small party in the left block, to vote for the SPD, even if a majority of the Green Party supporters dislikes coalition governments. By voting for the Green Party, they can increase the likelihood of a left-wing government, since they help the Green Party to overcome the five-percent hurdle. As long as ideological preferences of the supporters of one small party outweigh 
their dislike for coalition governments (which arguably will be the case), it is rational from their perspective to vote for their preferred small party.

Therefore, ideological considerations will typically trump unobserved preferences for public spending when voters make their electoral choices. For such reasons, the independence assumption is reasonable for the "parties in parliament" instrument. The number of parties in parliament can therefore, conditional on the control variables, be treated as effectively random. One way to confirm the validity of the instruments is through over-identification tests. Unfortunately, I cannot calculate such tests since I have only one instrument available. However, I experiment with additional instruments in the Appendix and find that the over-identification test is passed (see Table A.1 in the Appendix).

Table 3 reports the instrumental variables regressions using Two Stage Least Squares. This table mostly replicates the models reported in Table1, Model (I) includes the coalition dummy, the lagged expenditures per capita, and the year fixed effects. Model (II) adds the cabinet size variable. Model (III) the control variables already considered in Table 1.

Model (IV) adds a new control variable: the number of seats in parliament. The reason for including this variable is as follows. As repeatedly mentioned above, the number of seats in parliament is essentially fixed. However, the number is not completely fixed. In some states, the existence of so called Überhangmadate and Ausgleichsmandate might lead to parliaments with more seats than the default number. In practice, there are only a few Überhang- and Ausgleichsmandate in each election, if any. Still, not controlling for their existence could induce an omitted variable bias. Therefore, I control for the actual size of the parliament in Model IV. Details on these seats is offered in the Appendix.

The Kleibergen-Paap F-Statistic in Models I-IV is around 50 or higher. The first stage regressions, reported in Table A.3 in the Appendix, show that the instrument affects the potentially endogenous variable in the expected way: the more parties are in parliament, the more likely are coalition governments. 
The estimates for the coalition variable differ to some extent from the baseline results reported in Table1. The numerical values of the TSLS coefficient estimates for this variable is larger than in the baseline estimates. However, the estimates still suggest an economically unimportant effect: coalition governments spend at most 40 Euros per capita more than single-party governments. Moreover, the estimated coefficients are never significant at conventional significance levels. The cabinet size variable, on the other hand, has as in the baseline regressions a significant and mildly positive effect on expenditures.

Overall, while the numerical estimates are slightly larger, they continue to indicate that coalition governments do not lead to economically significant common pool problems in the German States. Even ignoring the statistical insignificance of the estimates for the moment and taking the numerical estimates at face value, it can only be concluded that coalition governments spend around 42 Euros per capita more than single-party governments. That is, coalition governments spend at most about $1 \%$ more than single-party governments. Cabinet size, on the other hand, has an effect that is roughly similar as suggested in the baseline regressions.

\section{$7 \quad$ Additional robustness tests}

In Table 4, I report a number of additional robustness checks. In Model I of this table, I estimate separate effects for the government fragmentation variables in West- and EastGermany. While the two parts of Germany have formally the same legislative structure, the East-German states operate in a somewhat different political and economic environment. One important political distinction is that the PDS plays a significant role in Eastern Germany. An economic distinction is the strong reliance on horizontal and vertical transfers of the East-German states. The results suggests, however, that the estimated effects of coalition governments and cabinet size do not differ significantly between East- and West- 
Germany and are similar to those reported in the standard TSLS regressions: coalitions have no statistically nor economically significant effect while cabinet size has a mild positive (yet insignificant) effect on aggregate expenditures. In Model II and III, I use a WestGerman and an East-German subsample to estimate Equation 1, Results regarding the coalition dummy and the cabinet size variable are similar, however. Interestingly, the coefficient for the cabinet size variable is significant and fairly large in Model III where only East-German States are included.

In Model IV, I report regressions without Bavaria and Mecklenburg-Western Pomerania. Mecklenburg-Western Pomerania has been consistently ruled by coalition governments. Bavaria, on the other hand, has been ruled for most of the sample period by a single-party government. Only at the end of the sample period, a coalition government took office for the first time in the recent history of this state. Results, however, are again almost identical to the baseline findings.

Model V reports regressions with an alternative coalition variable that takes the number of parties in the coalition into account. This variable is 1 for single party governments (since there is one party in government), 2 for all coalitions that included only two parties, and 3 for the SPD-FDP-Green Party coalitions that prevailed at different points in time in Brandenburg and Bremen, for the short-lived CDU-FDP-Schill Party coalition, and the CDU-Green Party-FDP coalition that assumed power in Saarland in 2009. The conclusions regarding the effect of coalition governments and cabinet size do not change, however.

\section{Conclusion}

The literature of the fiscal consequences of government fragmentation generally finds that coalition governments or large cabinets result in higher public expenditures. However, most studies exhibit some problematic features that put this conclusion into question. 
Cross-country studies have to cope with vastly differing institutional and cultural contexts. Studies at the sub-national level have mostly been conducted with data from fairly low levels of government, calling into question whether the results can be generalized to politically and economically powerful government tiers. Finally. the studv by Schaltegger and Feld (2009), while using data at the cantonal level and thus from the second highest tier of government in Switzerland, relies mostly on variation between cantons and does therefore not control for unobserved canton-specific effects.

This paper contributes to the literature by addressing each of these problematic features. Unlike cross-country studies, it uses variation from the relatively homogeneous German States. Unlike studies at low levels of government, it focuses on the state and thus the second highest tier of government in Germany, a tier that is both politically powerful and fiscally important. Unlike the study by Schaltegger and Feld (2009), it can estimate meaningful fixed effects models because of the large within-variation in the incidence of coalition governments and the size of the cabinet and thus control for unobserved state-level heterogeneity.

The results differ from those found in most previous studies, including those previous studies that study the common pool problem with German state data. The estimates suggest that coalition governments do not affect public spending. While the estimates for coalition governments exhibit a positive sign in instrumental variables regressions, they are neither in economic nor in statistical terms significantly different from zero. Consequently, coalition governments does not lead to significant common pool problems. Large cabinets, on the other hand, have at most only a mildly positive effect on public expenditures. The size of the estimates suggests that large cabinets do not lead to significant common pool problems either.

On the one hand, this conclusion might be specific to Germany. It is possible that parliamentary control or other institutional features in the German States are sufficiently strong 
to reduce the incentives for fiscal profligacy that result from government fragmentation. The literature has emphasized, for example, the role of formal fiscal rules or the strength of the finance minister (Poterba, 1994; von Hagen and Harden, 1995). All German States have similar fiscal rules and all state finance ministers have similar institutional powers. It is possible that either the fiscal rules are effective in addressing common pool problems related to government fragmentation, or that the finance ministers are capable to force the cabinet ministers to internalize the full costs of targeted public expenditures. On the

other hand, Jochimsen and Thomasius (2012) find that the strength of the finance minister varies with her personal traits as well. This source of variability in the power of the finance minister might explain why we find the mild positive effect of cabinet size on public spending.

Another interpretation of the results in this paper is that common pool problems are not particularly important for fiscal policy. This is a reasonable interpretation of the results because it is difficult to imagine that countries will continue to suffer from common pool problems caused by government fragmentation without developing at some point mechanisms to limit their severity. Nevertheless, further research is required to conclusively establish to what extent the findings in this paper have external validity.

\section{Acknowledgments}

I thank two referees for their helpful comments and suggestions. I am grateful to Kai-Uwe Schnapp for sharing his data on the structure of German state cabinets. I thank staff members of various German state governments and state parliaments - in particular Dirk Stangenberg, Elke Breitenbach, and Matthias Crone - for providing further information on the composition of state governments. I also thank participants at the 2012 meetings of the International Institute of Public Finance (IIPF) in Dresden and the International 
Society for New Institutional Economics (ISNIE) in Los Angeles for their comments and suggestions. All errors or omissions are mine. 


\section{References}

Alt, J. E. and R. C. Lowry (1994). Divided government and budget deficits: evidence from the States. American Political Science Review 88, 811-828.

Ashworth, J. and B. Heyndels (2005). Government fragmentation and budgetary policy in "good" and "bad" times in Flemish municipalities. Economics and Politics 17, 245-263.

Bandyopadhyay, S. and M. P. Oak (2008). Coalition governments in a model of parliamentary democracy. European Journal of Political Economy 24, 554-561.

Baum, C. F. (2005). Stata: the language of choice for time-series analysis. The Stata Journal 5, 46-63.

Bawn, K. and F. Rosenbluth (2006). Short versus long coalitions: electoral accountability and the size of the public sector. American Journal of Political Science 50, 251-265.

Borge, L.-E. (2005). Strong politicians, small deficits: evidence from Norwegian local governments. European Journal of Political Economy 21, 325-344.

Brennan, G. and J. Buchanan (1980). The power to tax: analytical foundations of a fiscal constitution. Cambridge: Cambridge University Press.

Bruno, G. S. F. (2005). Approximating the bias of the LSDV estimator for dynamic unbalanced panel data models. Economics Letters 87(3), 361-366.

Cameron, C. A., J. B. Gelbach, and D. L. Miller (2008). Bootstrap-based improvements for inference with clustered errors. Review of Economics and Statistics 90, 414-427.

De Haan, J. and J.-E. Sturm (1997). Political and economic determinants of OECD budget deficits and government expenditures: a reinvestigation. European Journal of Political Economy 13, 739-750. 
Devereux, M. P., B. Lockwood, and M. Redoano (2008). Do countries compete over corporate tax rates? Journal of Public Economics 92(5-6), 1210-1235.

Edin, P. A. and H. Ohlsson (1991). Political determinants of budget deficits: coalition effects versus minority effects. European Economic Review 35, 1597-1603.

Egger, P. and M. Koethenbuerger (2010). Government spending and legislative organization: quasi-experimental evidence from Germany. American Economic Journal: Applied Economics 2, 200-212.

Falco-Gimeno, A. and I. Jurado (2011). Minority governments and budget deficits: the role of the opposition. Europeam Journal of Political Economy 27, 554-565.

Galli, E. and S. Rossi (2002). Political business cycles: the case of the Western German Länder. Public Choice 110, 283-303.

Jochimsen, B. and R. Nuscheler (2011). The political economy of German Länder deficits. Applied Economics 43, 2399-2415.

Jochimsen, B. and S. Thomasius (2012). The perfect finance minister: whom to appoint as finance minister to balance the budget. DIW Working Paper 1188.

Judson, R. A. and A. L. Owen (1999). Estimating dynamic panel data models: a guide for macroeconomists. Economics Letters 65, 9-15.

Kipke, R. (2000). Gemeinden in der politischen Ordnung der Bundesrepublik Deutschland. In J. Bellers, R. Frey, and C. Rosenthal (Eds.), Einführung in die Kommunalpolitik. München.

Le Maux, B., Y. Rocaboy, and T. Goodspeed (2011). Political fragmentation, party ideology and public expenditures. Public Choice 147, 43-67. 
Nichols, A. and M. E. Schaffer (2007). Clustered standard errors in Stata. United Kingdom Stata Users' Group Meetings.

Nickell, S. J. (1981). Biases in dynamic models with fixed effects. Econometrica 49(6), $1417-1426$.

Perotti, R. and Y. Kontopoulos (2002). Fragmented fiscal policy. Journal of Public Economics 86, 191-222.

Pettersson-Lidbom, P. (2012). Does the size of the legislature affect the size of the government: evidence from two natural experiments. Journal of Public Economics 96, 269-278.

Pitlik, H., F. Schneider, and H. Strotmann (2005). Legislative malapportionment and the politicization of Germany's intergovernmental transfer system. Mimeo (University of Hohenheim).

Poterba, J. M. (1994). State responses to fiscal crises: the effects of budgetary institutions and politics. Journal of Political Economy 102(4), 799-821.

Reichard, C. (2001). Personeller Umbau und Herausforderungen an die Personalpolitik. In H.-U. Derlin (Ed.), Zehn Jahre Verwaltungsaufbau Ost - eine Evaluation. Baden-Baden.

Roodman, D. (2008a). How to do xtabond2: An introduction to "Difference" and "System" GMM in Stata. Center for Global Development Working Paper.

Roodman, D. (2008b). A note on the theme of too many instruments. Center for Global Development Working Paper.

Roubini, N. and J. Sachs (1989a). Government spending and budget deficits in the industrialized countries. Economic Policy 8, 99-132. 
Roubini, N. and J. Sachs (1989b). Political and economic determinants of budget deficits in the industrial democracies. European Economic Review 33, 903-938.

Schaltegger, C. and L. P. Feld (2009). Do large cabinets favor large governments? evidence on the fiscal commons problem for Swiss Cantons. Journal of Public Economics 93, 3547.

Schnapp, K. U. (2006). Einfluss der Bundespolitik auf Landtagswahlen. Eine Analyse des Wählerverhaltens auf Landesebene unter besonderer Berücksichtigung der Bundespolitik. Research Project of the German Research Foundation.

Seitz, H. (2000). Fiscal policy, deficits, and politics of subnational governments: the case of the German Länder. Public Choice 102(3-4), 183-218.

Seitz, H. (2008). Die Bundesbestimmtheit der Länderausgaben. Wirtschaftsdienst 88, $340-348$.

Shepsle, K. and B. Weingast (1981). Political preferences for the pork barrel: a generalization. American Journal of Political Science 25, 96-11.

Tridimas, G. (2011). The political economy of power-sharing. Europeam Journal of Political Economy 27, 328-342.

von Hagen, J. and I. J. Harden (1995). Budget processes and commitment to fiscal discipline. European Economic Review 39(3/4), 771-779.

Wagner, A. (1911). Staat in Nationalökonomischer Hinsicht. In Handwörterbuch der Staatswissenschaften (3 ed.), Volume 7, pp. 743-745. Jena: Lexis.

Weingast, B., K. Shepsle, and C. Johnsen (1981). The political economy of costs and benefits: a neoclassical approach to distributive politics. Journal of Political Economy 89(4), $642-664$. 
Woo, J. (2003). Economic, political, and institutional determinants of public deficits. Journal of Public Economics 87, 387-426. 
Table 1: The effect of COALition governments And CABINET SIZE ON REAL PUBLIC EXPENDITURES PER CAPITA, German States, 1975-2010, OLS estimations

\begin{tabular}{|c|c|c|c|c|}
\hline & I & II & III & IV \\
\hline \multirow[t]{3}{*}{ Coalition government } & 5.399 & & 6.149 & -2.937 \\
\hline & $(13.163)$ & & $(13.128)$ & $(14.977)$ \\
\hline & {$[\mathrm{p}=0.706]$} & & {$[\mathrm{p}=0.702]$} & {$[\mathrm{p}=0.892]$} \\
\hline \multirow[t]{3}{*}{ Cabinet size } & & 10.639 & 10.709 & $15.210^{* *}$ \\
\hline & & $(7.950)$ & $(7.953)$ & $(7.371)$ \\
\hline & & {$[\mathrm{p}=0.400]$} & {$[\mathrm{p}=0.382]$} & {$[\mathrm{p}=0.200]$} \\
\hline \multirow[t]{3}{*}{ Expenditures per cap.t-1 } & $0.900^{* * *}$ & $0.893^{* * *}$ & $0.893^{* * *}$ & $0.699^{* * *}$ \\
\hline & $(0.035)$ & $(0.034)$ & $(0.034)$ & $(0.044)$ \\
\hline & {$[\mathrm{p}=0.000]$} & {$[\mathrm{p}=0.000]$} & {$[\mathrm{p}=0.000]$} & {$[\mathrm{p}=0.000]$} \\
\hline \multirow[t]{3}{*}{ Revenues per cap. } & & & & $0.165^{* * *}$ \\
\hline & & & & $(0.036)$ \\
\hline & & & & {$[\mathrm{p}=0.016]$} \\
\hline \multirow[t]{3}{*}{ Left ideology } & & & & -11.847 \\
\hline & & & & $(25.148)$ \\
\hline & & & & {$[\mathrm{p}=0.836]$} \\
\hline \multirow[t]{3}{*}{ Right ideology } & & & & 12.600 \\
\hline & & & & $(19.157)$ \\
\hline & & & & {$[\mathrm{p}=0.558]$} \\
\hline \multirow[t]{3}{*}{ Unemployment rate } & & & & -1.635 \\
\hline & & & & $(5.364)$ \\
\hline & & & & {$[\mathrm{p}=0.820]$} \\
\hline \multirow[t]{3}{*}{ GDP per cap. } & & & & 0.000 \\
\hline & & & & $(0.005)$ \\
\hline & & & & {$[\mathrm{p}=0.978]$} \\
\hline \multirow[t]{3}{*}{ Share of old } & & & & -4.751 \\
\hline & & & & $(13.107)$ \\
\hline & & & & {$[\mathrm{p}=0.920]$} \\
\hline \multirow[t]{3}{*}{ Share of young } & & & & $38.878^{* * *}$ \\
\hline & & & & $(10.240)$ \\
\hline & & & & {$[\mathrm{p}=0.046]$} \\
\hline \multirow[t]{3}{*}{ Election year } & & & & $25.318^{*}$ \\
\hline & & & & $(13.936)$ \\
\hline & & & & {$[\mathrm{p}=0.000]$} \\
\hline Year dummies & Yes & Yes & Yes & Yes \\
\hline State dummies & Yes & Yes & Yes & Yes \\
\hline $\mathrm{AR}(1)$-test ( $\mathrm{p}$-value) & 0.276 & 0.279 & 0.280 & 0.248 \\
\hline $\mathrm{N}$ & 475 & 475 & 475 & 459 \\
\hline F & 615.478 & 676.243 & 672.350 & 760.785 \\
\hline $\begin{array}{l}\text { a This table presents OL } \\
\text { b The dependent variabl } \\
\text { c Stars indicate significar } \\
\text { d z-statistics in parenthe } \\
\text { e z-statistics and hypoth } \\
\text { standard errors. }\end{array}$ & $\begin{array}{l}\text { regressions } \\
\text { is real expe } \\
\text { ce levels at } \\
\text { s. } \\
\text { sis tests bas }\end{array}$ & $\begin{array}{l}\text { out and wi } \\
\text { lres per cap } \\
(*), 5 \%(* *) \\
\text { heterosce }\end{array}$ & $\begin{array}{l}\text { ate fixed eff } \\
1 \%(* * *) \text {. } \\
\text { city and au }\end{array}$ & relation robust \\
\hline
\end{tabular}


Table 2: The EFFeCt of COALITION GOvernments And CABINEt SIZE ON REAL PUBLIC EXPENDITURES PER CAPITA ON DIFFERENT SPENDING items, German states, 1975-2010, OLS estimations

\begin{tabular}{llllll}
\hline & I & II & III & IV & V \\
\hline \multirow{2}{*}{ Coalition government } & 2.843 & 1.444 & $-5.825^{*}$ & -0.622 & 0.671 \\
& $(3.324)$ & $(4.453)$ & $(3.424)$ & $(1.204)$ & $(2.767)$ \\
& {$[\mathrm{p}=0.556]$} & {$[\mathrm{p}=0.822]$} & {$[\mathrm{p}=0.206]$} & {$[\mathrm{p}=0.752]$} & {$[\mathrm{p}=0.736]$} \\
Cabinet size & 1.658 & 0.949 & $4.698^{* *}$ & $0.910^{*}$ & $2.751^{* * *}$ \\
& $(1.602)$ & $(1.975)$ & $(1.918)$ & $(0.469)$ & $(0.980)$ \\
Expenditures per cap.t-1 & $0.799^{* * *}$ & $0.828^{* * *}$ & $0.663^{* * *}$ & $0.802^{* * *}$ & $0.626^{* * *}$ \\
& $(0.029)$ & $(0.029)$ & $(0.102)$ & $(0.042)$ & $(0.077)$ \\
Year dummies & {$[\mathrm{p}=0.000]$} & {$[\mathrm{p}=0.000]$} & {$[\mathrm{p}=0.000]$} & {$[\mathrm{p}=0.000]$} & {$[\mathrm{p}=0.000]$} \\
State dummies & Yes & Yes & Yes & Yes & Yes \\
Control variables & Yes & Yes & Yes & Yes & Yes \\
\hline AR(1)-test (p-value) & Yes & Yes & Yes & Yes & Yes \\
N & 0.455 & 0.695 & 0.024 & 0.817 & 0.296 \\
\hline F & 443 & 443 & 443 & 459 & 459 \\
\hline T & 419.925 & 803.195 & 392.188 & 1514.246 & 60.132 \\
\hline
\end{tabular}

a This table presents OLS regressions with state fixed effects: Model I includes only the coalition dummy, Model II adds the cabinet size variable, Model III adds control variables, Model IV additionally controls for the number of seats in the state parliament.

b The dependent variable is expenditures per capita for either education (Model I), social services (Model II), health (Model III), public safety (Model IV), and infrastructure (Model V).

b Stars indicate significance levels at $10 \%(*), 5 \%(* *)$ and $1 \%(* * *)$.

c $\mathrm{z}$-statistics in parentheses.

d z-statistics and hypothesis tests based on heteroscedasticity and autocorrelation robust standard errors.

e Control variables for which results are omitted are: Revenues per cap., Left ideology, Right ideology, Unemployment rate, GDP per cap., Share of old, Share of young, Election year. 
Table 3: The effect of CoAlition governments and CABinet SIZE ON REAL PUBLIC EXPENDITURES PER CAPITA, GERMAN STATES, 1975-2010, TSLS ESTIMATIONS

\begin{tabular}{|c|c|c|c|c|}
\hline & I & II & III & IV \\
\hline \multirow[t]{2}{*}{ Coalition government } & -1.445 & 2.333 & 48.813 & 40.761 \\
\hline & $(-0.038)$ & $(0.061)$ & $(1.175)$ & $(0.978)$ \\
\hline \multirow[t]{2}{*}{ Cabinet size } & & 10.666 & $14.233^{* *}$ & $11.706^{*}$ \\
\hline & & $(1.326)$ & $(1.965)$ & $(1.735)$ \\
\hline \multirow[t]{2}{*}{ Expenditures per cap.t-1 } & $0.900^{* * *}$ & $0.893^{* * *}$ & $0.710^{* * *}$ & $0.708^{* * *}$ \\
\hline & $(25.754)$ & $(26.524)$ & $(15.518)$ & $(16.544)$ \\
\hline \multirow[t]{2}{*}{ Parliament size } & & & & $0.986^{*}$ \\
\hline & & & & $(1.748)$ \\
\hline Year dummies & Yes & Yes & Yes & Yes \\
\hline State dummies & Yes & Yes & Yes & Yes \\
\hline Control variables & No & No & Yes & Yes \\
\hline $\mathrm{AR}(1)$-test (p-value) & 0.273 & 0.278 & 0.430 & 0.311 \\
\hline $\mathrm{N}$ & 475 & 475 & 459 & 458 \\
\hline $\mathrm{F}$ & 621.657 & 683.458 & 752.855 & 748.457 \\
\hline Kleibergen-Paap Wald F-Statistic & 64.482 & 63.887 & 49.537 & 51.623 \\
\hline \multicolumn{5}{|c|}{$\begin{array}{l}\text { a This table presents TSLS regressions: Model I includes only the coalition dummy, Model II } \\
\text { adds the cabinet size variable, Model III adds control variables, Model IV additionally controls } \\
\text { for the number of seats in the state parliament. } \\
\text { b The dependent variable is real expenditures per capita. } \\
\text { b Stars indicate significance levels at } 10 \%(*), 5 \%(* *) \text { and } 1 \%(* * *) . \\
\text { c z-statistics in parentheses. } \\
\text { d z-statistics and hypothesis tests based on heteroscedasticity and autocorrelation robust standard } \\
\text { errors. } \\
\text { e The Cragg-Donald Wald F-Statistic is used to test for weak instruments. } \\
\text { f Control variables for which results are omitted are: Revenues per cap., Left ideology, Right } \\
\text { ideology, Unemployment rate, GDP per cap., Share of old, Share of young, Election year. }\end{array}$} \\
\hline
\end{tabular}


Table 4: The EFFECT of COALITION GOVERnMEnts And CABINET SIZE ON REAL PUblic EXPENDitures Per CAPita, German states, 1975-2010, RoBUSTNESS CHECKS, TSLS ESTIMATIONS

\begin{tabular}{|c|c|c|c|c|c|}
\hline & I & II & III & IV & V \\
\hline \multirow[t]{2}{*}{ Coalition government } & & 44.660 & 24.750 & 43.244 & 35.195 \\
\hline & & $(0.889)$ & $(0.373)$ & $(1.113)$ & $(0.994)$ \\
\hline \multirow[t]{2}{*}{ Coalition government $\times$ West } & 54.823 & & & & \\
\hline & $(0.997)$ & & & & \\
\hline \multirow{2}{*}{ Coalition government $\times$ East } & 2.753 & & & & \\
\hline & $(0.044)$ & & & & \\
\hline \multirow[t]{2}{*}{ Cabinet size } & & 9.614 & $55.655^{* *}$ & 9.159 & $11.807^{*}$ \\
\hline & & $(1.540)$ & $(2.038)$ & $(1.293)$ & $(1.756)$ \\
\hline \multirow[t]{2}{*}{ Cabinet size $\times$ West } & 10.206 & & & & \\
\hline & $(1.497)$ & & & & \\
\hline \multirow[t]{2}{*}{ Cabinet size $\times$ East } & 20.126 & & & & \\
\hline & $(0.829)$ & & & & \\
\hline \multirow[t]{2}{*}{ Expenditures per cap.t-1 } & $0.704^{* * *}$ & $0.687^{* * *}$ & 0.127 & $0.730^{* * *}$ & $0.707^{* * *}$ \\
\hline & $(15.952)$ & $(12.561)$ & $(1.412)$ & $(17.130)$ & $(16.637)$ \\
\hline Year dummies & Yes & Yes & Yes & Yes & Yes \\
\hline State dummies & Yes & Yes & Yes & Yes & Yes \\
\hline Control variables & Yes & Yes & Yes & Yes & Yes \\
\hline $\mathrm{AR}(1)$-test (p-value) & 0.502 & 0.534 & 0.630 & 0.183 & 0.238 \\
\hline $\mathrm{N}$ & 458 & 368 & 90 & 405 & 458 \\
\hline $\mathrm{F}$ & 670.643 & 708.172 & 119.790 & 710.032 & 736.960 \\
\hline Kleibergen-Paap Wald F-Statistic & 18.739 & 37.450 & 9.692 & 52.777 & 56.564 \\
\hline \multicolumn{6}{|c|}{$\begin{array}{l}\text { a This table presents robustness checks using TSLS: Model I estimates separate effects of coalition governments and } \\
\text { cabinet size in West- and East Germany, Model II estimates the regression with a West-German subsample, Model } \\
\text { III estimates the regression with an East-German subsample, Model IV estimates the regression after dropping } \\
\text { Bavaria and Mecklenburg-Western Pomerania, Model V estimates the regression with a redefined coalition dummy. } \\
\text { b The dependent variable is real expenditures per capita. } \\
\text { c Stars indicate significance levels at } 10 \%(*), 5 \%\left({ }^{* *}\right) \text { and } 1 \%(* * *) \text {. } \\
\text { d z-statistics in parentheses. } \\
\text { e z-statistics and hypothesis tests based on heteroscedasticity and autocorrelation robust standard errors. } \\
\text { f The Cragg-Donald Wald F-Statistic is used to test for weak instruments. } \\
\text { g Control variables for which results are omitted are: Revenues per cap., Left ideology, Right ideology, Unemploy- } \\
\text { ment rate, GDP per cap., Share of old, Share of young, Election year. }\end{array}$} \\
\hline
\end{tabular}




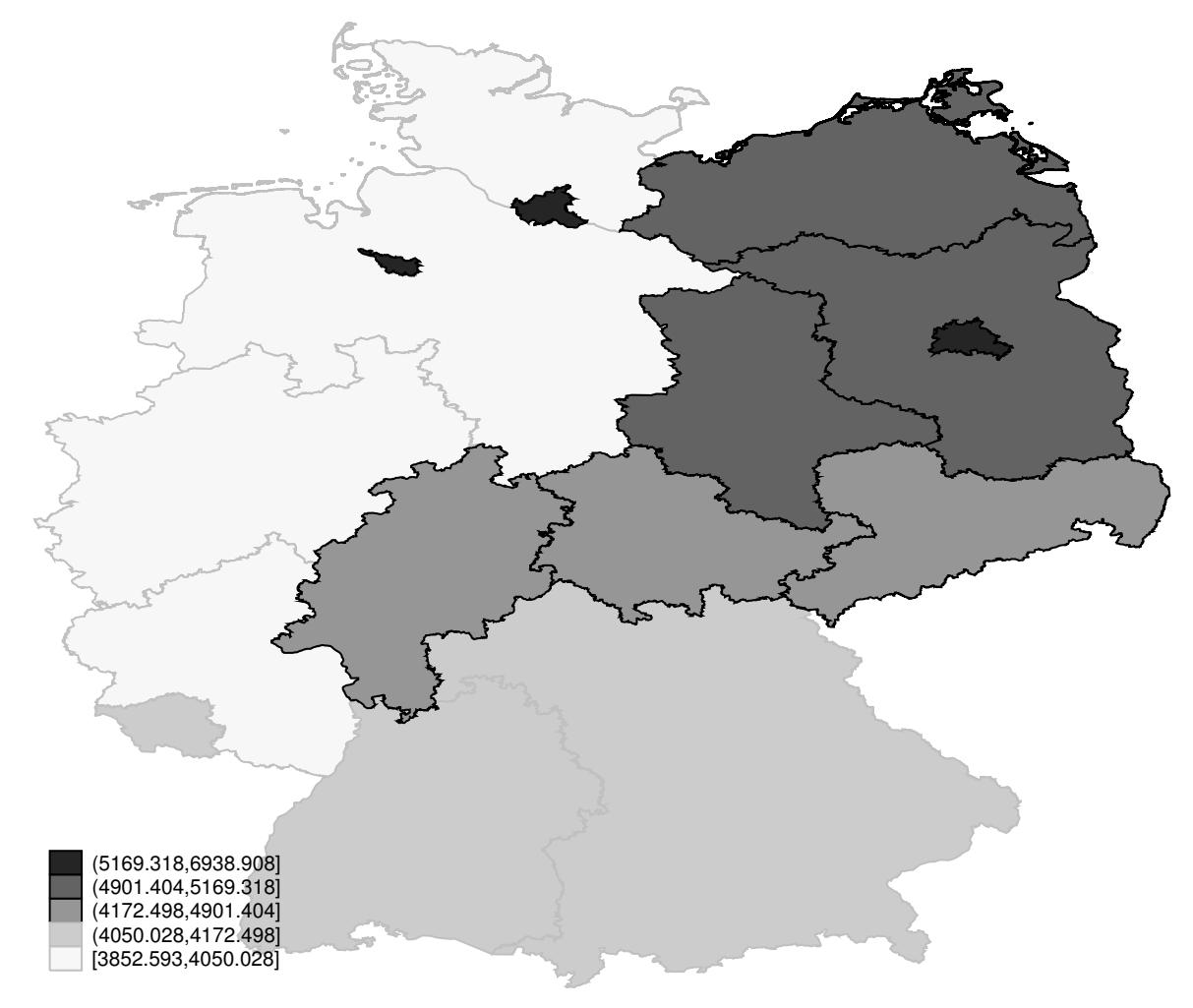

Figure 1: MAP of the 16 German States With AVERAGe REAL EXPENDitures PeR CAPITA DURING THE 1975-2010 PERIOD

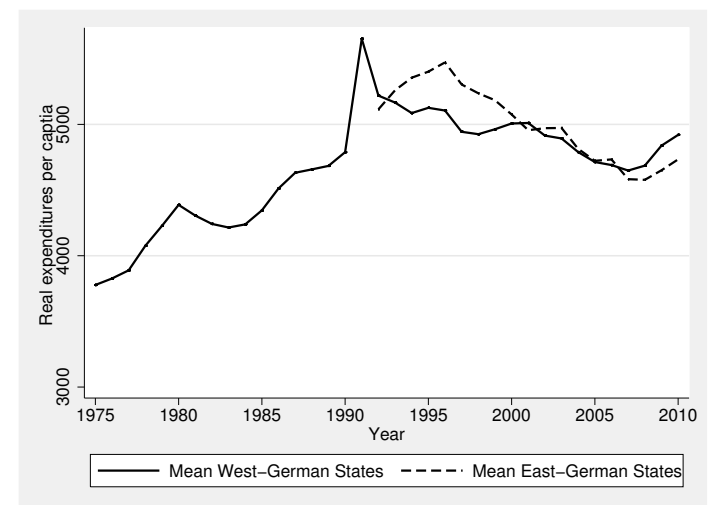

Figure 2: Development of (UnWeighted) AVERAge state Expenditures Per CAPITA DURING THE 1975-2010 PERIOD 


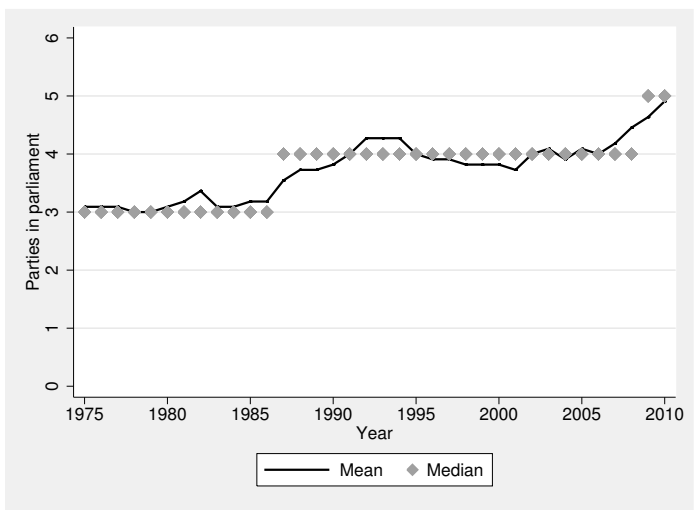

(a) Number of PARTies in PARLiament in WEST-GERMANY

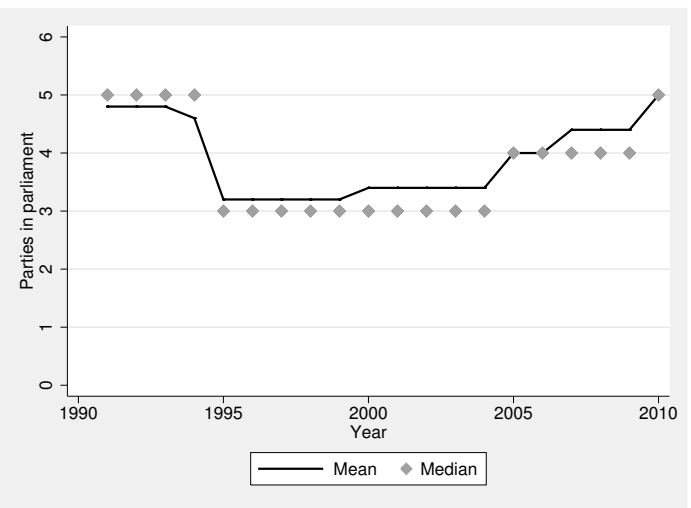

(b) Number of PARTies in PARLiAMENT in EAST-GERMANY

Figure 3: Development of the number of Parties in West- and East-German STATE PARLIAMENTS

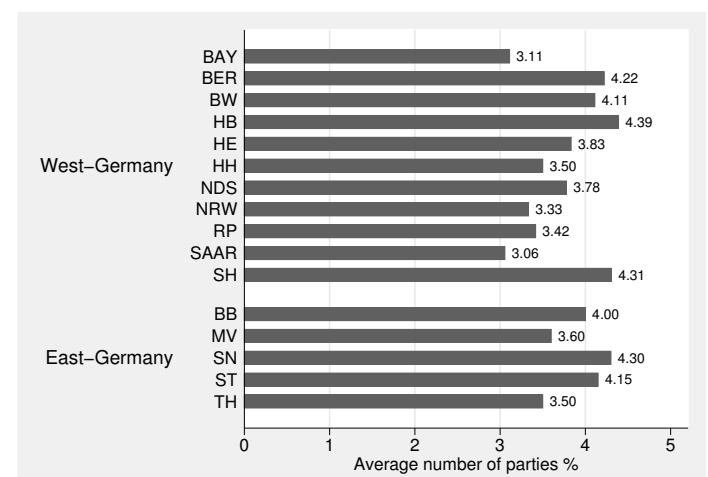

Figure 4: Average number of Parties in the German state Parliaments Definition of the state codes: Bay (Bavaria), BB (Brandenburg), Ber (Berlin), BW (BadenWuerttemberG) HB (Bremen), he (Hesse), hH (Hamburg), MV (Mecklendurg-Western PomeraNia), NDS (Lower-Saxony), NRW (North Rhine-Westphalia), RP (Rhineland-Palatinate), SAAR (SaArland) SH (Schleswig-Holstein), SN (Saxony), ST (Saxony-Anhalt), TH (Thuringia) 


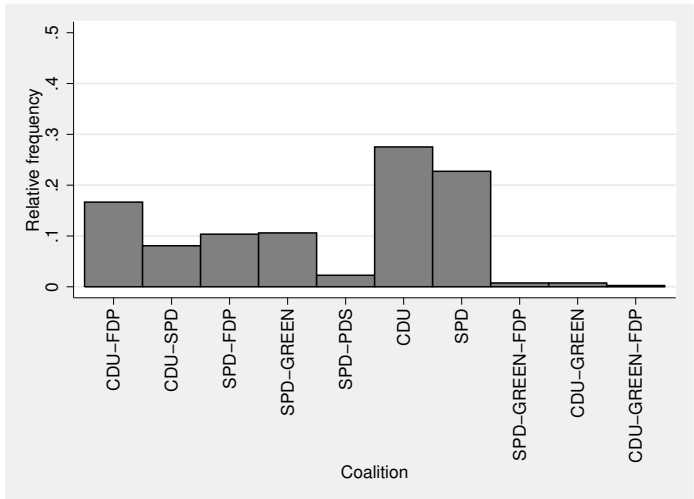

(a) CoAlitions And Single-PARTy GOVERNMENTS IN WEST-GERMANY

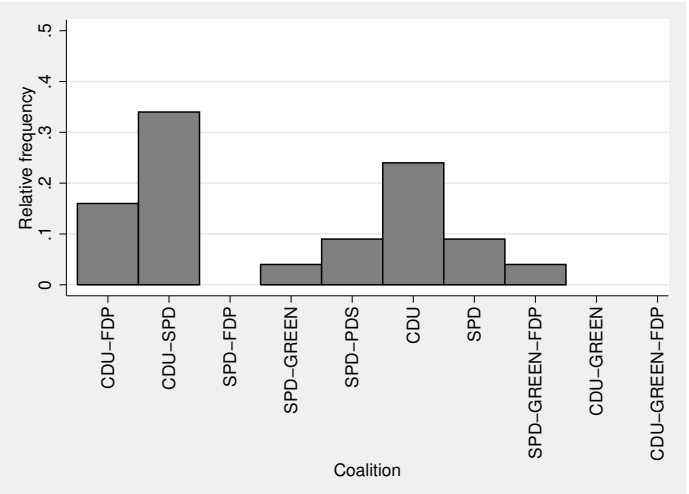

(b) CoAlitions AND SINGLE-PARTY GOVERNMENTS IN EAST-GERMANY

Figure 5: Frequency of Different types of GOVERnMENT IN WeST- AND EASTGERMANY

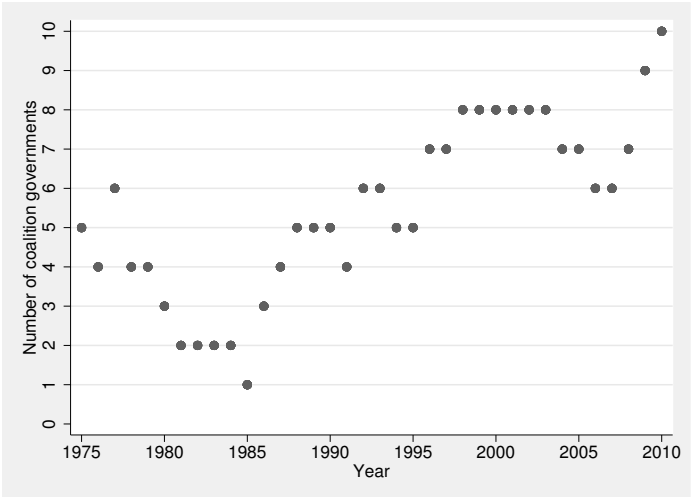

(a) Number of COALITION GOVERNMENTS IN WEST-GERMANY

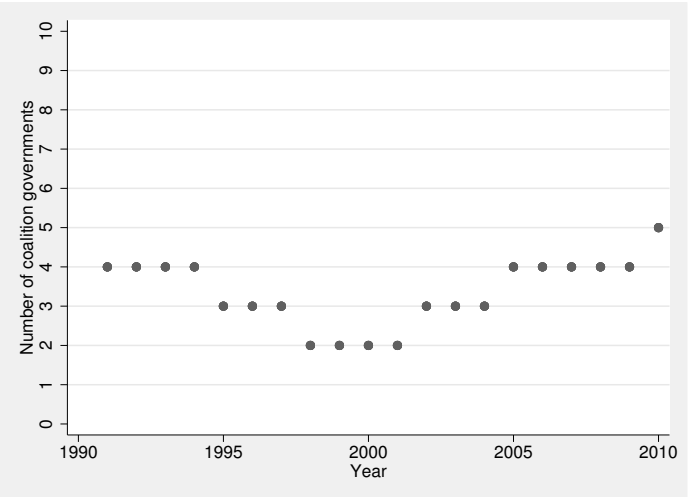

(b) Number OF COALITION GOVERNMENTS IN EAST-GERMANY

Figure 6: OVER-TIME DEVELOPMENTS OF THE NUMBER OF COALITION GOVERNMENTS In WeSt- and East-Germany 


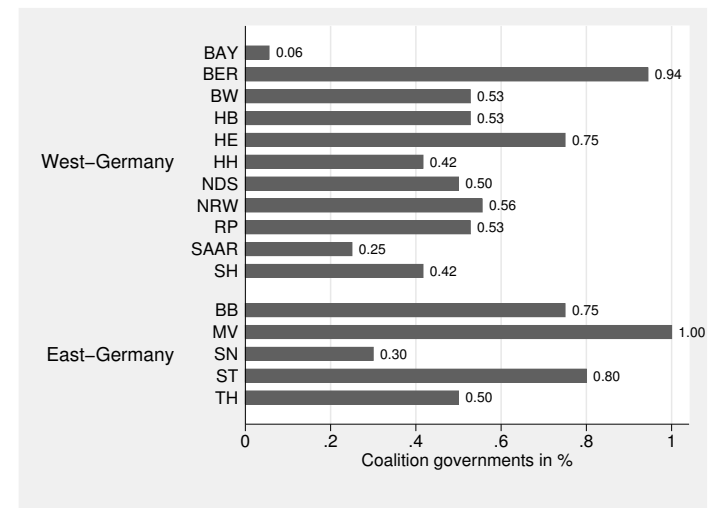

Figure 7: Frequency of CoAlition governments in German States Definition of

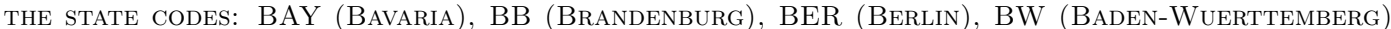
hB (Bremen), he (Hesse), hH (Hamburg), mV (Mecklenburg-Western Pomerania), NDS (LowerSaxony), NRW (North Rhine-Westphalia), RP (Rhineland-Palatinate), SAar (SaArland) SH (Schleswig-Holstein), SN (Saxony), ST (Saxony-Anhalt), TH (Thuringia)

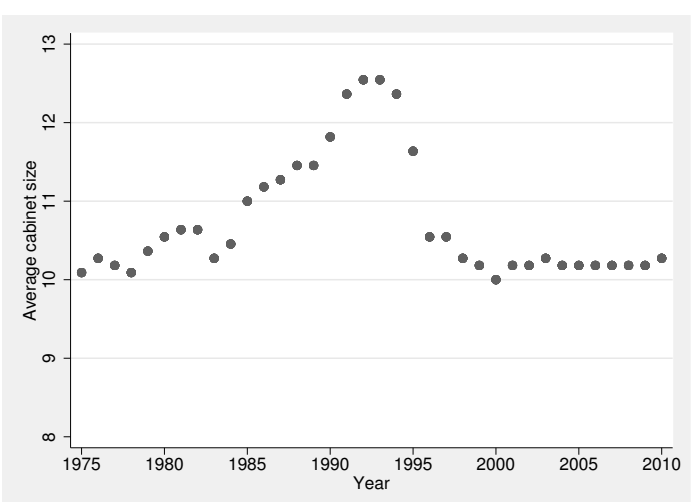

(a) Average Cabinet size in WestGermany

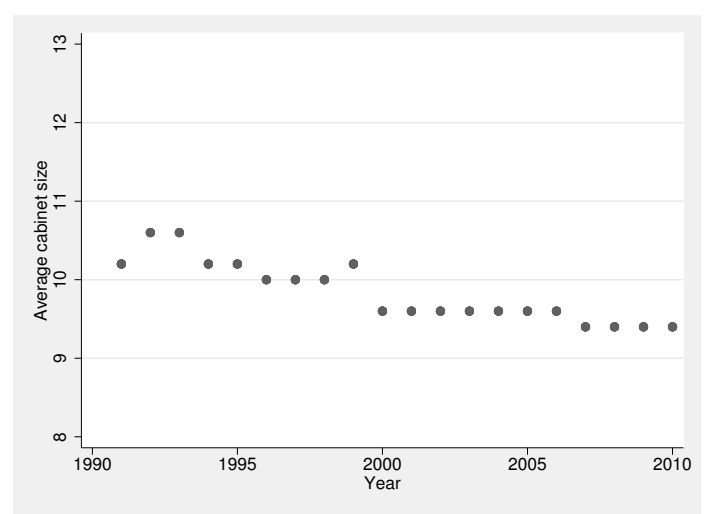

(b) Average Cabinet size in EastGERMANY

Figure 8: Development of the AVERAge CABinet Size in West- And EastGermany 


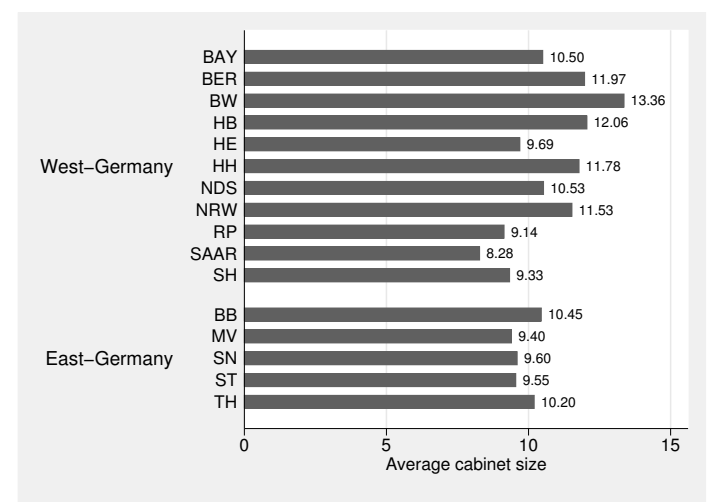

Figure 9: Average Cabinet size in German States Definition of the state codes: Bay (Bavaria), BB (Brandenburg), Ber (Berlin), BW (Baden-Wuerttemberg) hB (Bremen), he (Hesse), hH (Hamburg), MV (Mecklenburg-Western Pomerania), NDS (Lower-Saxony), NRW (North Rhine-Westphalia), RP (Rhineland-Palatinate), SAAR (SaArland) SH (SchleswigHolstein), SN (Saxony), ST (Saxony-Anhalt), TH (Thuringia)

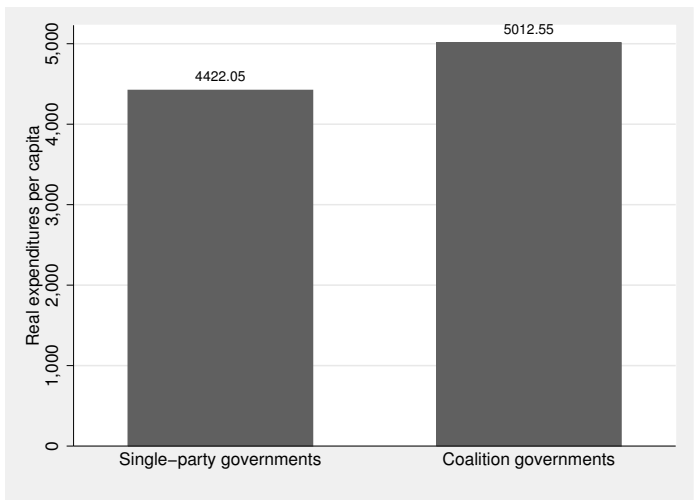

(a) Conlition governments

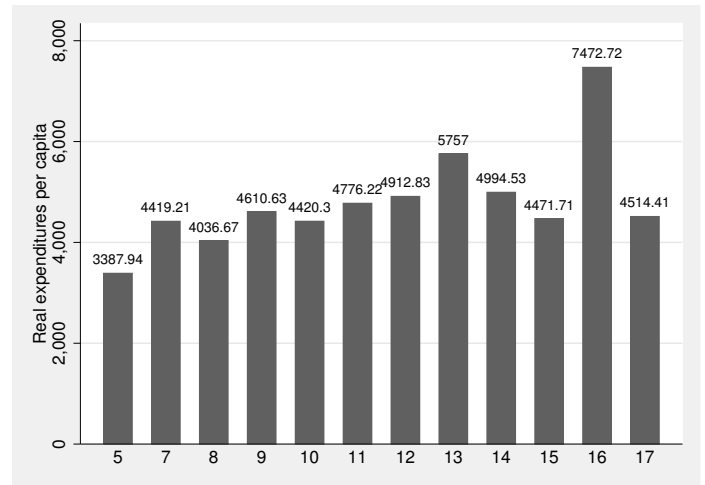

(b) Cabinet Size

Figure 10: CoAlition governments, CABInet size, And AVERAGe PUbliC ExpenDitures in the German States, 1975-2010 


\section{Appendix}

\section{A.1 Details on the coding of the cabinet size variable}

Using the data provided by Schnapp (2006) to determine the number of cabinet ministers involves some difficult choices. The most important issues are the following. First, certain "Staatsekretäre" (State Secretaries) have the same status as cabinet ministers in some states (usually a Staatssekretär is a deputy of a minister and subordinate to him). In particular, they can participate and vote in cabinet meetings. Second, some cabinets have a minister who is responsible for "federal affairs", whereas in other cabinets this task is assumed by either the state prime minister or by cabinet ministers whose prime responsibility is a different policy area. Third, each state has a "Staatskanzlei" (or alternatively a "Staatsministerium") which is either led by a minister or a Staatssekretär. The Staatskanzlei is different from the other ministries as it is essentially the office of the state prime minister and coordinates policies among all other ministries. Fourth, sometimes one minister leads two separate ministries.

I made the following decisions regarding the problematic cases described above. First, I do not count Staatssekretäre as members of the cabinet, except certain cases where the Staatskanzlei is led by a Staatssekretär (see below) or where my data source explicitly indicated that they were government members with seat and vote in the cabinet. Second, I count the ministry for federal affairs as a separate ministry if it is led by a minister who has no other cabinet post. (i. e. if it is led by a minister who has another cabinet post - i. e. the state prime minister or some other cabinet minister- I do not count it as a separate ministry.) Third, I do not count the Staatskanzlei as a separate ministry except if the head of the Staatskanzlei (irrespective of whether he is formally a minister or a Staatssekretär) is responsible for some additional tasks (for example, the Staatssekretär in the cabinet formed in Baden-Wuerrtemberg from 2001 to 2006 was also responsible for 
"European issues", consequently I count the Staatskanzlei as a separate ministry in this cabinet). Fourth, if one minister heads two separate ministers, I increase the cabinet size by two.

There were some additional but relatively minor decisions I had to make, for example regarding a reshuffling of the cabinet within an legislative period (I ascribe any changes inbetween election years to the year in which the reshuffling took place irrespective of whether it happened in the first or second half) or how to treat an arrangement where a member of the cabinet is a Staatssekretär but is called a minister (a so called "Staatssekretär mit der Amtsbezeichnung Minister" - I count this Staatssekretär / minister as a proper member of the cabinet).

\section{A.2 Coalitions involving non-mainstream parties}

Apart from the five mainstream parties, the party system consists of a multitude of fringe parties. Most notably, there are several extreme right-wing parties which manage to enter state parliaments from time to time (by obtaining more than five percent of the votes) 20 The five mainstream parties, however, have always shunned them: extreme right-wing parties were never part of any coalition government. Usually these extreme right-wing parties only last one or two legislative period in parliament because they fail to receive more than five percent of the votes in subsequent elections. Apart from the extreme rightwing parties, there are a number of regionally based "protest" parties, i. e. parties which try to offer an alternative to the established parties. The most notable was the so called Schill Party (named after the founder of the party, the official name was Partei Rechtsstaatlicher Offensive). This main focus of this party were law and order issues. After entering the state parliament in Hamburg in the election of 2001, the Schill Party even formed a three-party

\footnotetext{
${ }^{20}$ Most notably the National Democratic Party of Germany (NPD), the Democratic Peoples' Union (DVU), and the (German) Republicans (REP).
} 
coalition government with the CDU and the FDP, with the CDU as the senior partner. However, this government soon fall apart amids a scandal. Subsequently, the Schill Party became irrelevant. In the following, I treat the CDU-FDP-Schill Party government during the 2001-2004 period in Hamburg as a CDU-FDP government and thus as a right-wing government.

Another important protest party was the STATT Party. This party entered the state parliament of Hamburg in 1993. Subsequently, it concluded a "coalition-like" agreement with the SPD by which the SPD received the support of the STATT Party. In exchange the SPD agreed to appoint a number of ministers without party affiliations but chosen by the STATT Party. While the STATT party thus played an important role for the government of Hamburg during the 1993-1997 period, I nonetheless code this period as a sole SPD government since no official members of the STATT Party were represented in the cabinet.

\section{A.3 Überhangmadate and Ausgleichsmandate}

The Überhangmadate and Ausgleichsmandate emerge in some states because of the attempt of the electoral laws in these states to combine elements of both proportional and plurality rule by means of the so called personalized proportional electoral system. In a common variant of this electoral system, voters can cast two votes. With their first vote (Erststimme), they vote for a candidate within their voting district. With their second vote (Zweitstimme), they vote for a state party list. Seats in the state parliament are alloted to the parties in general according their shares in the Zweitstimme. The share of the Zweitstimme therefore basically defines the number of seats that should accrue to a party. In the allocation of seats, candidates who are directly elected in their districts are given primacy over candidates who are only on the party list. That is, seats that belong to a party according to its share of the Zweitstimme are first filled with candidates who 
have won in their districts. Any remaining seats are filled with candidates that are on the party list (and have not won in their districts).

It can happen that the number candidates from a party who win in their districts exceeds the number of seats a state can claim according to its share of the Zweitstimme. Since it is not possible to deny a candidate who has won in his district a seat in parliament, the party gets a Überhangmandat, which increases the size of the parliament. Since this party has now more seats than it should get according to its Zweitstimme, the electoral laws in some states require that the other parties get so called Ausgleichsmadate. The purpose of the Ausgleichsmandate is to correct the imbalance in the distribution of seats introduced by the Überhangmandate. The Ausgleichsmandate, if they exist, increase the size of the parliament further.

\section{A.4 Alternative instruments}

In Table A.1, I report a number of robustness tests with alternative instruments, partly to check the robustness of the regressions with the number of parties in parliament instrument and partly to have the ability to calculate over-identification tests. These additional instruments are the actual vote share of the FDP and the Green Party. Clearly, the larger the share of votes that these two parties get, the less likely it will be that a single-party government is formed. However, it is possible that these variables should not be excluded from the second stage regression because if these two parties are actually part of the government, their vote share might have a direct effect on public expenditures (the conditional independence assumption is more suspect for these instruments than for the parties in parliament instrument).

Model I in Table A.1 reports the result of a regression that replicates Model IV in Table 3. but uses the vote share of the FDP and the Green Party as instruments. Since two instruments are available for one endogenous variable, Hansen-J over-identification tests 
Table A.1: The effect of COAlition GOVERNMENTS AND CABINET SIZE ON REAL PUBLIC EXPENDITURES PER CAPITA, German STATES, 19752010, TSLS ESTIMATIONS, ALTERNATIVE INSTRUMENTS

\begin{tabular}{lll}
\hline & I & II \\
\hline & & \\
Coalition government & 18.125 & 25.741 \\
& $(0.490)$ & $(0.708)$ \\
Cabinet size & $16.192^{* *}$ & $16.068^{* *}$ \\
& $(2.229)$ & $(2.219)$ \\
Expenditures per cap.t-1 & $0.687^{* * *}$ & $0.689^{* * *}$ \\
& $(16.270)$ & $(16.221)$ \\
Parliament size & $1.038^{*}$ & $1.057^{*}$ \\
& $(1.893)$ & $(1.924)$ \\
Year dummies & Yes & Yes \\
State dummies & Yes & Yes \\
Control variables & Yes & Yes \\
\hline AR(1)-test (p-value) & 0.235 & 0.198 \\
N & 422 & 422 \\
F & 618.073 & 621.015 \\
Kleibergen-Paap Wald F-Statistic & 28.042 & 23.982 \\
Hansen-J & 0.391 & 0.536 \\
\hline & & \\
& &
\end{tabular}

a This table presents the TSLS regressions: Model I reports regressions using the share of the Green Party and the FDP as instrument, Model II reports regressions with the share of the Green Party, the share of the FDP, and the number of parties in parliament as instruments.

b The dependent variable is real expenditures per capita.

b Stars indicate significance levels at $10 \%\left({ }^{*}\right), 5 \%(* *)$ and $1 \%(* * *)$.

c $z$-statistics in parentheses.

d z-statistics and hypothesis tests based on heteroscedasticity and autocorrelation robust standard errors.

e The Cragg-Donald Wald F-Statistic is used to test for weak instruments.

f Control variables for which results are omitted are: Revenues per cap., Left ideology, Right ideology, Unemployment rate, GDP per cap., Share of old, Share of young, Election year. 
can be calculated. The test, reported at the bottom of the table, does not indicate that the instruments are invalid. The results with respect to the coalition dummy and the cabinet size variable are almost similar to those reported in the previous sections. These two variables are also strong instruments as indicated by the weak identification tests.

Model II replicates Model I by additionally including in the instrument set the number of parties in parliament. In this model, the Hansen-J over-identification test can be interpreted as a test for the validity of the "parties in parliament" instrument. The Hansen-J test is insignificant. The results for the coalition size and cabinet size variables are similar to those reported in the previous section. While the validity of the over-identification tests relies on the validity of at least one of the instruments, there is a reasonable chance that at least one of the instruments is valid. It is therefore reassuring that the over-identification tests are not rejected.

\section{A.5 Dynamic panel data estimators}

One problematic feature of the estimates reported in Table1 in the main text is the reliance of the large-T properties of the dataset to deal with the Nickell-bias. An alternative is to rely on dynamic panel data estimators that have been developed to address the problem of biased estimates in samples with small $\mathrm{T}$. In this section, I report the results from estimating Model 1 1 with four different dynamic panel data estimators: the Bias Corrected Least Square Dummy Variables estimator, th Difference-GMM estimator, the SystemGMM estimator, and the Anderson-Hsiao estimator.

One feature of the Difference and System-GMM estimators is that the number of instruments increases rapidly with the number of time periods, resulting in the so called "large instrument problem" and unreliable inference (Roodman, 2008b). Clearly, these estimators are designed for large-N-small-T datasets. Indeed, Judson and Owen (1999) do not recommend the Difference- and System-GMM estimators with large T datasets. 
According to Judson and Owen (1999), the Anderson-Hsiao estimator performs better than System-GMM and Difference-GMM in datasets with large T (albeit not as well as the simple fixed effects estimator). In contrast to the GMM-estimators, the number of instruments in the Anderson-Hsiao estimator is relatively small. This estimator also starts out by differencing Model 1. As instrument for the first difference lagged dependent variable, the variant of the Anderson-Hsiao estimator that I apply here uses the second lag of the level. The problem with the Anderson-Hsiao estimator is that it can be very inefficient if the second lag of the dependent variable is not strongly correlated with the first difference of the lagged dependent variable.

Table A.2 reports the result of estimating Model 1 with the four dynamic panel data estimators. Model I reports the Bias Corrected LSDV regressions, Model II the DifferenceGMM regressions. Model III the System-GMM regressions. Model IV reports the AndersonHsiao regressions using the second lag of the dependent variable as instrument. In Models II-IV, I continue to use the number of parties in the state parliament as instrument for the coalition government dummy. In Model I, the coalition variable is not instrumented as the Bias Corrected LSDV estimator has not yet been extend to account for endogenous regressors.

The coefficient for the coalition dummy is insignificant and numerically close to 0 in the Bias Corrected LSDV regressions. It is positive and significant in the GMM regressions. The numerical value of the estimate is around 100 in the Difference-GMM model, it is somewhat smaller in the System-GMM model with 71. However, note that the diagnostic tests do not perform well in these models. In particular, the Hansen-J test has a value of 1 , which points to the existence of a large instruments problem, confirming that the GMM models are unreliable in large panels. The Anderson-Hsiao regression, too, produces a fairly large (122.55) but insignificant estimate for the coalition dummy. Note, however, once more that the diagnostic tests indicate that these models are unreliable. In particular, 
the weak-identification statistic is very low for this model. Further inspection of the firststage results suggests that the small value of the test statistic can be explained by the fact that the second lag of the dependent variable is not significantly correlated with the first difference (the number of parties in parliament continues to be significantly and positively related to the likelihood that a coalition government will be formed).

Results for the cabinet size variable also do not differ significantly between the dynamic panel data models and the baseline results. The estimated coefficients are in around 10 and significant in Model I where the Bias Corrected LSDV estimator is used.

Table A.2: The EFFect of COALition GOVERnMEnts And CABINET SIZE ON REAL PUBLIC EXPENDITURES PER CAPITA, German states, 1975-2010, Dynamic Panel Data MODELS

\begin{tabular}{|c|c|c|c|c|}
\hline & I & II & III & IV \\
\hline \multirow[t]{2}{*}{ Coalition government } & -1.144 & $98.720^{* *}$ & $71.243^{*}$ & 122.551 \\
\hline & $(-0.052)$ & $(2.046)$ & $(1.719)$ & $(0.877)$ \\
\hline \multirow[t]{2}{*}{ Cabinet size } & $12.469^{*}$ & 10.090 & 5.754 & 10.257 \\
\hline & $(1.790)$ & $(0.834)$ & $(0.803)$ & $(0.998)$ \\
\hline \multirow[t]{2}{*}{ Expenditures per cap.t-1 } & $0.740^{* * *}$ & $0.668^{* * *}$ & $0.826^{* * *}$ & $0.691^{*}$ \\
\hline & $(16.649)$ & $(13.593)$ & $(11.010)$ & $(1.838)$ \\
\hline Year dummies & Yes & Yes & Yes & Yes \\
\hline Control variables & Yes & Yes & Yes & Yes \\
\hline AR(1)-test (p-value) & 0.204 & & & 0.330 \\
\hline $\mathrm{N}$ & 458 & 442 & 458 & 442 \\
\hline$\chi^{2}$ & & 598.412 & 2382.288 & \\
\hline $\mathrm{F}$ & & & & 16.226 \\
\hline Hansen-J & & 1.000 & 1.000 & \\
\hline GMM AR(1)-test (p-value) & & 0.009 & 0.009 & \\
\hline GMM AR(2)-test (p-value) & & 0.610 & 0.489 & \\
\hline Instrument-No. & . & 79 & 79 & 2 \\
\hline Kleibergen-Paap Wald F-Statistic & & & & 2.533 \\
\hline \multicolumn{5}{|c|}{$\begin{array}{l}\text { a This table presents robustness checks using dynamic panel data estimators: Model I are Bias } \\
\text { Corrected LSDV results, Model II are Difference-GMM results, Model III are System-GMM } \\
\text { results, Model IV are Anderson-Hsiao regressions with the second lag of the dependent variable } \\
\text { as instrument for its first difference. } \\
\text { b The dependent variable is real expenditures per capita. } \\
\text { c Stars indicate significance levels at } 10 \%(*), 5 \%(* *) \text { and } 1 \%(* * *) \text {. } \\
\text { d z-statistics in parentheses. } \\
\text { e z-statistics and hypothesis tests based on bootstrapped (Bias Corrected LSDV), one-step ro- } \\
\text { bust (Difference-GMM and System GMM regressions) or heteroscedasticity and autocorrelation } \\
\text { robust (Anderson-Hsiao regressions) standard errors. } \\
\text { f Control variables for which results are omitted are: Revenues per cap., Left ideology, Right } \\
\text { ideology, Unemployment rate, GDP per cap., Share of old, Share of young, Election year. }\end{array}$} \\
\hline
\end{tabular}




\section{A.6 First-stage regressions, data sources, and summary statistics}

Table A.3: First-Stage REgRession of COALition GOVERNMENTS ON PARTIES IN PARLIAMENT, GERMAN STATES, 1975-2010

\begin{tabular}{|c|c|c|c|c|}
\hline & I & II & III & IV \\
\hline Parties in parliament & $\begin{array}{l}0.267^{* * *} \\
(8.030)\end{array}$ & $\begin{array}{l}0.267^{* * *} \\
(7.993)\end{array}$ & $\begin{array}{l}0.235^{* * *} \\
(7.038)\end{array}$ & $\begin{array}{l}0.242^{* * *} \\
(7.185)\end{array}$ \\
\hline \multicolumn{5}{|l|}{ Share of FDP } \\
\hline \multicolumn{5}{|l|}{ Share of Green Party } \\
\hline Cabinet size & & $\begin{array}{l}-0.003 \\
(-0.160)\end{array}$ & $\begin{array}{l}0.024 \\
(1.342)\end{array}$ & $\begin{array}{l}0.035^{*} \\
(1.836)\end{array}$ \\
\hline Expenditures per cap.t-1 & $\begin{array}{l}0.000^{*} \\
(1.658)\end{array}$ & $\begin{array}{l}0.000 \\
(1.642)\end{array}$ & $\begin{array}{l}-0.000^{*} \\
(-1.742)\end{array}$ & $\begin{array}{l}-0.000^{*} \\
(-1.811)\end{array}$ \\
\hline Parliament size & & & & $\begin{array}{l}-0.004^{* *} \\
(-2.016)\end{array}$ \\
\hline Year dummies & Yes & Yes & Yes & Yes \\
\hline State dummies & Yes & Yes & Yes & Yes \\
\hline Control variables & No & No & Yes & Yes \\
\hline $\mathrm{N}$ & 475 & 475 & 459 & 458 \\
\hline $\mathrm{F}$ & 10.991 & 11.473 & 21.885 & 22.264 \\
\hline \multicolumn{5}{|c|}{$\begin{array}{l}\text { a This table presents the first-stage regressions for the regressions reported in Table } 3 \\
\text { b The dependent variable is whether a state is ruled by a coalition government. } \\
\text { c Stars indicate significance levels at } 10 \%(*), 5 \%(* *) \text { and } 1 \%(* * *) \text {. } \\
\text { d z-statistics in parentheses. } \\
\text { e z-statistics and hypothesis tests based on heteroscedasticity and autocorrelation and au- } \\
\text { tocorrelation robust standard errors. } \\
\text { f Control variables for which results are omitted are: Revenues per cap., Left ideology, } \\
\text { Right ideology, Unemployment rate, GDP per cap., Share of old, Share of young, Election } \\
\text { year. }\end{array}$} \\
\hline
\end{tabular}


Table A.4: Definition And source of VARiables

\begin{tabular}{|c|c|c|}
\hline Label & Description & Source \\
\hline Expenditures per cap. & $\begin{array}{l}\text { Real consolidated expenditures per capita (de- } \\
\text { flated by federal CPI). Expenditures are consol- } \\
\text { idated between states and their localities. }\end{array}$ & $\begin{array}{l}\text { German Federal Statis- } \\
\text { tical Office }\end{array}$ \\
\hline $\begin{array}{l}\text { Education expendi- } \\
\text { tures per cap. }\end{array}$ & $\begin{array}{l}\text { Real net consolidated expenditures per capita for } \\
\text { education (deflated by federal CPI). Net expen- } \\
\text { ditures are consolidated between states and their } \\
\text { localities and corrected for certain transfers from } \\
\text { other parts of the public sector. }\end{array}$ & $\begin{array}{l}\text { German Federal Statis- } \\
\text { tical Office }\end{array}$ \\
\hline $\begin{array}{l}\text { Social expenditures per } \\
\text { cap. }\end{array}$ & $\begin{array}{l}\text { Real net consolidated expenditures per capita for } \\
\text { social services (deflated by federal CPI). Net ex- } \\
\text { penditures are consolidated between states and } \\
\text { their localities and corrected for certain transfers } \\
\text { from other parts of the public sector. }\end{array}$ & $\begin{array}{l}\text { German Federal Statis- } \\
\text { tical Office }\end{array}$ \\
\hline $\begin{array}{l}\text { Health expenditures } \\
\text { per cap. }\end{array}$ & $\begin{array}{l}\text { Real net consolidated expenditures per capita for } \\
\text { social services (deflated by federal CPI). Net ex- } \\
\text { penditures are consolidated between states and } \\
\text { their localities and corrected for certain transfers } \\
\text { from other parts of the public sector. }\end{array}$ & $\begin{array}{l}\text { German Federal Statis- } \\
\text { tical Office }\end{array}$ \\
\hline $\begin{array}{l}\text { Public safety expendi- } \\
\text { tures per cap. }\end{array}$ & $\begin{array}{l}\text { Real net consolidated expenditures per capita for } \\
\text { public safety (deflated by federal CPI). Net expen- } \\
\text { ditures are consolidated between states and their } \\
\text { localities and corrected for certain transfers from } \\
\text { other parts of the public sector. }\end{array}$ & $\begin{array}{l}\text { German Federal Statis- } \\
\text { tical Office }\end{array}$ \\
\hline $\begin{array}{l}\text { Infrastructure expendi- } \\
\text { tures per cap. }\end{array}$ & $\begin{array}{l}\text { Real net consolidated expenditures for traffic and } \\
\text { communications (deflated by federal CPI). Net ex- } \\
\text { penditures are consolidated between states and } \\
\text { their localities and corrected for certain transfers } \\
\text { from other parts of the public sector. }\end{array}$ & $\begin{array}{l}\text { German Federal Statis- } \\
\text { tical Office }\end{array}$ \\
\hline Coalition government & $\begin{array}{l}\text { Dummy variable }=1 \text { if government is formed by a } \\
\text { coalition of parties. }\end{array}$ & $\begin{array}{l}\text { Own construc- } \\
\text { tion based on } \\
\text { www.tagesschau.de }\end{array}$ \\
\hline Cabinet size & Number of ministers in the cabinet. & $\begin{array}{l}\text { Own construction } \\
\text { based on Schnapp } \\
(2006) \text { and information } \\
\text { supplied by state } \\
\text { governments or state } \\
\text { parliaments. }\end{array}$ \\
\hline Parties in parliament & Number of parties in the state parliament. & www.election.de \\
\hline Revenues per cap. & $\begin{array}{l}\text { Real revenues per capita (deflated by federal CPI). } \\
\text { Revenues are consolidated between states and } \\
\text { their localities. }\end{array}$ & $\begin{array}{l}\text { German Federal Statis- } \\
\text { tical Office }\end{array}$ \\
\hline Left ideology & $\begin{array}{l}\text { Dummy }=1 \text { if government is formed by left- } \\
\text { leaning parties (i. e. for SPD, SPD-Green Party, } \\
\text { and SPD-PDS governments). }\end{array}$ & $\begin{array}{l}\text { Own construc- } \\
\text { tion based on } \\
\text { www.tagesschau.de }\end{array}$ \\
\hline Right ideology & $\begin{array}{l}\text { Dummy }=1 \text { if government is formed by right- } \\
\text { leaning parties (i. e. for CDU and CDU-FDP gov- } \\
\text { ernments). }\end{array}$ & $\begin{array}{l}\text { Own construc- } \\
\text { tion based on } \\
\text { www.tagesschau.de }\end{array}$ \\
\hline Unemployment & State unemployment rate. & $\begin{array}{l}\text { German } \\
\begin{array}{l}\text { Agency oderal } \\
\text { ment }\end{array}\end{array}$ \\
\hline GDP per cap. & Real GDP per capita (deflated by federal CPI). & $\begin{array}{l}\text { German Federal and } \\
\text { State Statistical Offices } \\
\text { (Arbeitskreis VGR der } \\
\text { Länder) }\end{array}$ \\
\hline Share of old & Share of "old" ( $\geq 65$ years) in state population. & $\begin{array}{l}\text { German Federal Statis- } \\
\text { tical Office }\end{array}$ \\
\hline Share of young & Share of "young" ( $\leq 15$ years $)$ in state population. & $\begin{array}{l}\text { German Federal Statis- } \\
\text { tical Office }\end{array}$ \\
\hline Election year & Dummy $=1$ if state election year. & $\begin{array}{l}\text { Own construc- } \\
\text { tion based on } \\
\text { www.bundeswahlleiter.de }\end{array}$ \\
\hline Parliament size & Number of seats in parliament. & $\begin{array}{l}\text { German Federal Statis- } \\
\text { tical Office }\end{array}$ \\
\hline
\end{tabular}


Table A.5: Summary Statistics

\begin{tabular}{|c|c|c|c|c|c|c|}
\hline Variable & & Mean & Std. Dev. & Min. & Max. & $\mathbf{N}$ \\
\hline \multirow[t]{3}{*}{ Expenditures per cap. } & overall & 4752.904 & 1032.661 & 3179.423 & 7746.345 & 475 \\
\hline & between & & 885.706 & 3870.982 & 6959.696 & 16 \\
\hline & within & & 458.898 & 3283.635 & 6225.218 & 29.688 \\
\hline \multirow{3}{*}{$\begin{array}{l}\text { Education expendi- } \\
\text { tures per cap. }\end{array}$} & overall & 1081.836 & 194.924 & 725.734 & 1658.934 & 467 \\
\hline & between & & 150.579 & 901.850 & 1452.110 & 16 \\
\hline & within & & 120.721 & 810.796 & 1396.853 & 29.188 \\
\hline \multirow{3}{*}{$\begin{array}{l}\text { Social expenditures per } \\
\text { cap. }\end{array}$} & overall & 730.943 & 289.638 & 269.108 & 1589.493 & 467 \\
\hline & between & & 215.402 & 461.664 & 1275.407 & 16 \\
\hline & within & & 180.711 & 278.797 & 1161.214 & 29.188 \\
\hline \multirow{3}{*}{$\begin{array}{l}\text { Health expenditures } \\
\text { per cap. }\end{array}$} & overall & 271.524 & 164.954 & 115.182 & 919.224 & 467 \\
\hline & between & & 86.581 & 172.406 & 495.608 & 16 \\
\hline & within & & 140.989 & -55.694 & 811.156 & 29.188 \\
\hline \multirow{3}{*}{$\begin{array}{l}\text { Public safety expendi- } \\
\text { tures per cap. }\end{array}$} & overall & 360.223 & 109.633 & 178.895 & 653.015 & 475 \\
\hline & between & & 95.391 & 255.702 & 608.618 & 16 \\
\hline & within & & 47.198 & 245.117 & 476.646 & 29.688 \\
\hline \multirow{3}{*}{$\begin{array}{l}\text { Infrastructure expendi- } \\
\text { tures per cap. }\end{array}$} & overall & 174.218 & 53.676 & 1.829 & 355.262 & 475 \\
\hline & between & & 39.791 & 118.579 & 273.696 & 16 \\
\hline & within & & 38.985 & 18.792 & 378.046 & 29.688 \\
\hline \multirow[t]{3}{*}{ Coalition government } & overall & 0.528 & 0.500 & 0.000 & 1.000 & 475 \\
\hline & between & & 0.245 & 0.057 & 1.000 & 16 \\
\hline & within & & 0.442 & -0.414 & 1.471 & 29.688 \\
\hline \multirow[t]{3}{*}{ Cabinet size } & overall & 10.575 & 1.857 & 5.000 & 17.000 & 475 \\
\hline & between & & 1.369 & 8.257 & 13.457 & 16 \\
\hline & within & & 1.224 & 6.403 & 14.632 & 29.688 \\
\hline \multirow[t]{3}{*}{ Parties in parliament } & overall & 3.762 & 0.888 & 2.000 & 7.000 & 475 \\
\hline & between & & 0.444 & 3.057 & 4.429 & 16 \\
\hline & within & & 0.768 & 1.962 & 6.334 & 29.688 \\
\hline \multirow[t]{3}{*}{ Revenues per cap. } & overall & 4323.279 & 832.469 & 2733.492 & 7458.146 & 459 \\
\hline & between & & 691.436 & 3575.866 & 5859.317 & 16 \\
\hline & within & & 489.938 & 2695.959 & 6395.827 & 28.688 \\
\hline \multirow{3}{*}{ Left ideology } & overall & 0.341 & 0.475 & 0.000 & 1.000 & 475 \\
\hline & between & & 0.236 & 0.000 & 0.743 & 16 \\
\hline & within & & 0.415 & -0.402 & 1.198 & 29.688 \\
\hline \multirow[t]{3}{*}{ Right ideology } & overall & 0.425 & 0.495 & 0.000 & 1.000 & 475 \\
\hline & between & & 0.307 & 0.000 & 1.000 & 16 \\
\hline & within & & 0.396 & -0.460 & 1.314 & 29.688 \\
\hline \multirow[t]{3}{*}{ Unemployment } & overall & 10.714 & 4.786 & 2.100 & 22.100 & 475 \\
\hline & between & & 4.594 & 5.454 & 19.133 & 16 \\
\hline & within & & 2.667 & 1.745 & 19.345 & 29.688 \\
\hline \multirow[t]{3}{*}{ GDP per cap. } & overall & 24448.760 & 6996.149 & 13488.820 & 46840.990 & 475 \\
\hline & between & & 5598.929 & 18186.260 & 38879.420 & 16 \\
\hline & within & & 4439.226 & 11615.050 & 32410.330 & 29.688 \\
\hline \multirow{3}{*}{ Share of old } & overall & 17.181 & 2.505 & 11.643 & 24.677 & 475 \\
\hline & between & & 1.190 & 15.494 & 20.100 & 16 \\
\hline & within & & 2.275 & 12.018 & 22.547 & 29.688 \\
\hline \multirow[t]{3}{*}{ Share of young } & overall & 16.100 & 2.473 & 10.772 & 23.631 & 475 \\
\hline & between & & 1.565 & 13.631 & 17.924 & 16 \\
\hline & within & & 2.001 & 12.441 & 22.469 & 29.688 \\
\hline \multirow{3}{*}{ Election year } & overall & 0.234 & 0.424 & 0.000 & 1.000 & 475 \\
\hline & between & & 0.027 & 0.200 & 0.286 & 16 \\
\hline & within & & 0.423 & -0.052 & 1.034 & 29.688 \\
\hline \multirow[t]{3}{*}{ Parliament size } & overall & 123.587 & 48.159 & 50.000 & 241.000 & 474 \\
\hline & between & & 45.855 & 50.886 & 214.600 & 16 \\
\hline & within & & 13.073 & 89.987 & 200.044 & 29.625 \\
\hline
\end{tabular}




\section{Bisher erschienene Diskussionspapiere}

Nr. 165 Baskaran, Thushyanthan: Coalition governments, cabinets size, and the common pool problem: evidence from the German States, July 2013

Nr. 164 Baskaran, Thushyanthan: Taxation and democratization, July 2013

Nr. 163 Baskaran, Thushyanthan; Mariana Lopes da Fonseca: The economics and empirics of tax competition: a survey, Juli 2013

Nr. 162 Aytimur, Refik Emre: Importance of Status Quo when Lobbying a Coalition Government, Juni 2013

Nr. 161 Aytimur, Refik Emre: Extreme Parties and Political Rents, Juni 2013

Nr. 160 Strulik, Holger: Optimal Aging with Uncertain Death, Juni 2013

Nr. 159 Prettner, Klaus; Strulik, Holger: Trade and Productivity: The Family Connection Redux, Juni 2013

Nr. 158 Vogt, Nora; Bizer, Kilian: Lock-in effects in competitive bidding schemes for payments for ecosystem services, Juni 2013

Nr. 157 Baskaran, Thushyanthan: Identifying local tax mimicking: administrative borders and a policy reform, Juni 2013

Nr. 156 Herwartz, Helmut; Walle, Yabibal M.: State dependence in the finance-growth nexus: a functional coefficient approach, Juni 2013

Nr. 155 Krenz, Astrid: Cross-country heterogeneity and endogeneity bias in life satisfaction estimations-macro- and micro-level evidence for advanced, developing and transition countries, Mai 2013

Nr. 154: Krenz, Astrid: Services Sector's Concentration: the European Union, Greece, and the New Economic Geography, Mai 2013

Nr. 153: Ahmed, Junaid; Martinez-Zarzoso, Inmaculada: Blessing or Curse: The Stabilizing Role of Remittances, Foreign Aid and FDI to Pakistan, Mai 2013

Nr: 152: Strulik, Holger; Werner, Katharina: 50 is the New 30 - Long-run Trends of Schooling and Retirement Explained by Human Aging, März 2013

Nr. 151: Dalgaard, Carl-Johan; Strulik,Holger: The History Augmented Solow Model, März 2013

Nr. 150: Strulik, Holger; Trimborn, Timo: The Dark Side of Fiscal Stimulus, Januar 2013

Nr. 149: Prettner, Klaus: Public education, technological change and economic prosperity, Januar 2013

Nr. 148: Lankau, Matthias; Bicskei, Marianna; Bizer, Kilian: Cooperation Preferences in the Provision of Public Goods: An Experimental Study on the Effects of Social Identity, Dezember 2012

Nr. 147: Krenz, Astrid: Modeling Services Sectors' Agglomeration within a New Economic Geography Model, Dezember 2012

Nr. 146: Krenz, Astrid: A Panel Co-integration Analysis of Industrial and Services Sectors' Agglomeration in the European Union, Dezember 2012

Nr. 145: Strulik, Holger: Knowledge and Growth in the Very Long Run, November 2012

Nr. 144: Baskaran, Thushyanthan: Ideology and fiscal policy: quasi-experimental evidence from the German States, Oktober 2012

Nr. 143: Ehlers, Tim; Schwager, Robert: Honest Grading, Grade Inflation and Reputation, Oktober 2012

Nr. 142: Gehringer, Agnieszka: Another look at the determinants of current account imbalances in the European Union: An empirical assessment, Oktober 2012 
Nr. 141: Strulik, Holger; Werner, Katharina: Life Expectancy, Labor Supply, and Long-Run Growth: Reconciling Theory and Evidence, September 2012

Nr. 140: Strulik, Holger; Prettner, Klaus; Prskawetz, Alexia: The Past and Future of Knowledgebased Growth, September 2012

Nr. 139: Prettner, Klaus; Trimborn, Timo: Demographic change and R\&D-based economic growth: reconciling theory and evidence, September 2012

Nr. 138: König, Jörg; Ohr, Renate: Homogeneous groups within a heterogeneous community Evidence from an index measuring European economic integration, August 2012

Nr. 137: Schwager, Robert: Student Loans in a Tiebout Model of Higher Education, Juli 2012

Nr. 136: Martínez-Zarzoso, Inmaculada: Exporting and Productivity: Evidence for Egypt and Morocco, April 2012

Nr. 135: König, Jörg; Ohr, Renate: Messung ökonomischer Integration in der Europäischen Union Entwicklung eines EU-Integrationsindexes -, April 2012

Nr. 134: Gehringer, Agnieszka: Financial liberalization, growth, productivity and capital accumulation: The case of European integration, März 2012

Nr. 133: Berner, Eike; Birg, Laura: Retailers and Consumers. The pass-through of import price changes, März 2012

Nr. 132: Gehringer, Angnieszka: Current accounts in Europe: implications of the external imbalances for the future of the common monetary policy, März 2012

Nr. 131: Ohr, Renate; Özalbayrak, Mehmet: The Euro - A „MUST“ for Small European States?, Januar 2012

Nr. 130: Zeddies, Götz: Der Euro als Triebfeder des deutschen Exports?, November 2011

Nr. 129: Geishecker, Ingo; Siedler, Thomas: Job Loss Fears and (Extreme) Party Identification: First Evidence from Panel Data, Oktober 2011

Nr. 128: König, Jörg; Ohr, Renate: Small but Beautiful? Economic Impacts of the Size of Nations in the European Union, August 2011

Nr. 127: Schüder, Stefan: Monetary Policy Trade-Offs in a Portfolio Model with Endogenous Asset Supply, Juni 2011

Nr. 126: Hiller, Sanne: The Export Promoting Effect of Emigration: Evidence from Denmark, Juni 2011

Nr. 125: Martínez-Zarzoso, Inmaculada; Voicu, Anca M.; Vidovic, Martina: CEECs Integration into Regional and Global Production Networks, Mai 2011

Nr. 124: Roth, Felix; Gros, Daniel; Nowak-Lehmann D., Felicitas: Has the Financial Crisis eroded Citizens' Trust in the European Central Bank? Panel Data Evidence for the Euro Area, 1999-2011, Mai 2011, Revised Version März 2012

Nr. 123 Dreher, Axel; Vreeland, James Raymond : Buying Votes and International Organizations, Mai 2011

Nr. 122: Schürenberg-Frosch, Hannah: One Model fits all? Determinants of Transport Costs across Sectors and Country Groups, April 2011

Nr. 121: Verheyen, Florian: Bilateral Exports from Euro Zone Countries to the US - Does Exchange Rate Variability Play a Role?, April 2011

Nr. 120: Ehlers, Tim: University Graduation Dependent on Family's Wealth, Ability and Social Status, April 2011

Nr. 119: Cho, Seo-Young; Dreher, Axel; Neumayer, Eric: The Spread of Anti-trafficking Policies Evidence from a New Index, März 2011

Nr. 118: Cho, Seo-Young; Vadlamannati, Krishna Chaitanya: Compliance for Big Brothers: An Empirical Analysis on the Impact of the Anti-trafficking Protocol, Februar 2011 
Nr. 117: Nunnenkamp, Peter; Öhler, Hannes: Donations to US based NGOs in International Development Cooperation: How (Un-)Informed Are Private Donors?, Februar 2011

Nr. 116: Geishecker, Ingo; Riedl, Maximilian: Ordered Response Models and Non-Random Personality Traits: Monte Carlo Simulations and a Practical Guide, Revised Version Februar 2012

Nr. 115: Dreher, Axel; Gassebner, Martin; Siemers, Lars-H. R.: Globalization, Economic Freedom and Human Rights, Oktober 2010

Nr. 114: Dreher, Axel; Mikosch, Heiner; Voigt, Stefan: Membership has its Privileges - The Effect of Membership in International Organizations on FDI, Oktober 2010

Nr. 113: Fuchs, Andreas; Klann, Nils-Hendrik: Paying a Visit: The Dalai Lama Effect on International Trade, Oktober 2010

Nr. 112: Freitag, Stephan: Choosing an Anchor Currency for the Pacific, Oktober 2010

Nr. 111: Nunnenkamp, Peter; Öhler, Hannes: Throwing Foreign Aid at HIV/AIDS in Developing Countries: Missing the Target?, August 2010

Nr. 110: Ohr, Renate; Zeddies, Götz: „Geschäftsmodell Deutschland“ und außenwirtschaftliche Ungleichgewichte in der EU, Juli 2010

Nr. 109: Nunnenkamp, Peter; Öhler, Hannes: Funding, Competition and the Efficiency of NGOs: An Empirical Analysis of Non-charitable Expenditure of US NGOs Engaged in Foreign Aid, Juli 2010

Nr. 108: Krenz, Astrid: La Distinction reloaded: Returns to Education, Family Background, Cultural and Social Capital in Germany, Juli 2010

Nr. 107: Krenz, Astrid: Services sectors' agglomeration and its interdependence with industrial agglomeration in the European Union, Juli 2010

Nr. 106: Krenz, Astrid; Rübel, Gerhard: Industrial Localization and Countries' Specialization in the European Union: An Empirical Investigation, Juli 2010

Nr. 105: Schinke, Jan Christian: Follow the Sun! How investments in solar power plants in Sicily can generate high returns of investments and help to prevent global warming, Juni 2010

Nr. 104: Dreher, Axel; Sturm, Jan-Egbert; Vreeland, James Raymon: Does membership on the Security Council influence IMF conditionality?, Juni 2010

Nr. 103: Öhler, Hannes; Nunnenkamp, Peter; Dreher, Axel: Does Conditionality Work? A Test for an Innovative US Aid Scheme, Juni 2010

Nr. 102: Gehringer, Agnieszka: Pecuniary Knowledge Externalities in a New Taxonomy: Knowledge Interactions in a Vertically Integrated System, Juni 2010

Nr. 101: Gehringer, Agnieszka: Pecuniary Knowledge Externalities across European Countries - are there leading Sectors?, Juni 2010

Nr. 100: Gehringer, Agnieszka: Pecuniary Knowledge Externalities and Innovation: Intersectoral Linkages and their Effects beyond Technological Spillovers, Juni 2010

Nr. 99: Dreher, Axel; Nunnenkamp, Peter; Öhler, Hannes: Why it pays for aid recipients to take note of the Millennium Challenge Corporation: Other donors do!, April 2010

Nr. 98: Baumgarten, Daniel; Geishecker, Ingo; Görg, Holger: Offshoring, tasks, and the skill-wage pattern, März 2010

Nr. 97: Dreher, Axel; Klasen, Stephan; Raymond, James; Werker, Eric: The costs of favoritism: Is politically-driven aid less effective?, März 2010

Nr. 96: Dreher, Axel; Nunnenkamp, Peter; Thiele, Rainer: Are 'New' Donors Different? Comparing the Allocation of Bilateral Aid between Non-DAC and DAC Donor Countries, März 2010

Nr. 95: Lurweg, Maren; Westermeier, Andreas: Jobs Gained and Lost through Trade - The Case of Germany, März 2010 
Nr. 94: Bernauer, Thomas; Kalbhenn, Anna; Koubi, Vally; Ruoff, Gabi: On Commitment Levels and Compliance Mechanisms - Determinants of Participation in Global Environmental Agreements, Januar 2010

Nr. 93: Cho, Seo-Young: International Human Rights Treaty to Change Social Patterns - The Convention on the Elimination of All Forms of Discrimination against Women, Januar 2010

Nr. 92: Dreher, Axel; Nunnenkamp, Peter; Thiel, Susann; Thiele, Rainer: Aid Allocation by German NGOs: Does the Degree of Public Refinancing Matter?, Januar 2010

Nr. 91: Bjørnskov, Christian; Dreher, Axel; Fischer, Justina A. V.; Schnellenbach, Jan: On the relation between income inequality and happiness: Do fairness perceptions matter?, Dezember 2009

Nr. 90: Geishecker, Ingo: Perceived Job Insecurity and Well-Being Revisited: Towards Conceptual Clarity, Dezember 2009

Nr. 89: Kühl, Michael: Excess Comovements between the Euro/US dollar and British pound/US dollar exchange rates, November 2009

Nr. 88: Mourmouras, Alex, Russel, Steven H.: Financial Crises, Capital Liquidation and the Demand for International Reserves, November 2009

Nr. 87: Goerke, Laszlo, Pannenberg, Markus: An Analysis of Dismissal Legislation: Determinants of Severance Pay in West Germany, November 2009

Nr. 86: Marchesi, Silvia, Sabani, Laura, Dreher, Axel: Read my lips: the role of information transmission in multilateral reform design, Juni 2009

Nr. 85: Heinig, Hans Michael: Sind Referenden eine Antwort auf das Demokratiedilemma der EU?, Juni 2009

Nr. 84: El-Shagi, Makram: The Impact of Fixed Exchange Rates on Fiscal Discipline, Juni 2009

Nr. 83: Schneider, Friedrich: Is a Federal European Constitution for an Enlarged European Union Necessary? Some Preliminary Suggestions using Public Choice Analysis, Mai 2009

Nr. 82: Vaubel, Roland: Nie sollst Du mich befragen? Weshalb Referenden in bestimmten Politikbereichen - auch in der Europapolitik - möglich sein sollten, Mai 2009

Nr. 81: Williamson, Jeffrey G.: History without Evidence: Latin American Inequality since 1491, Mai 2009

Nr. 80: Erdogan, Burcu: How does the European Integration affect the European Stock Markets?, April 2009

Nr. 79: Oelgemöller, Jens; Westermeier, Andreas: RCAs within Western Europe, März 2009

Nr. 78: Blonski, Matthias; Lilienfeld-Toal, Ulf von: Excess Returns and the Distinguished Player Paradox, Oktober 2008

Nr. 77: Lechner, Susanne; Ohr, Renate: The Right of Withdrawal in the Treaty of Lisbon: A game theoretic reflection on different decision processes in the EU, Oktober 2008

Nr. 76: Kühl, Michael: Strong comovements of exchange rates: Theoretical and empirical cases when currencies become the same asset, Juli 2008

Nr. 75: Höhenberger, Nicole; Schmiedeberg, Claudia: Structural Convergence of European Countries, Juli 2008

Nr. 74: Nowak-Lehmann D., Felicitas; Vollmer, Sebastian; Martinez-Zarzoso, Inmaculada: Does Comparative Advantage Make Countries Competitive? A Comparison of China and Mexico, Juli 2008

Nr. 73: Fendel, Ralf; Lis, Eliza M.; Rülke, Jan-Christoph: Does the Financial Market Believe in the Phillips Curve? - Evidence from the G7 countries, Mai 2008

Nr. 72: Hafner, Kurt A.: Agglomeration Economies and Clustering - Evidence from German Firms, Mai 2008 
Nr. 71: Pegels, Anna: Die Rolle des Humankapitals bei der Technologieübertragung in Entwicklungsländer, April 2008

Nr. 70: Grimm, Michael; Klasen, Stephan: Geography vs. Institutions at the Village Level, Februar 2008

Nr. 69: Van der Berg, Servaas: How effective are poor schools? Poverty and educational outcomes in South Africa, Januar 2008

Nr. 68: Kühl, Michael: Cointegration in the Foreign Exchange Market and Market Efficiency since the Introduction of the Euro: Evidence based on bivariate Cointegration Analyses, Oktober 2007

Nr. 67: Hess, Sebastian; Cramon-Taubadel, Stephan von: Assessing General and Partial Equilibrium Simulations of Doha Round Outcomes using Meta-Analysis, August 2007

Nr. 66: Eckel, Carsten: International Trade and Retailing: Diversity versus Accessibility and the Creation of "Retail Deserts", August 2007

Nr. 65: Stoschek, Barbara: The Political Economy of Enviromental Regulations and Industry Compensation, Juni 2007

Nr. 64: Martinez-Zarzoso, Inmaculada; Nowak-Lehmann D., Felicitas; Vollmer, Sebastian: The Log of Gravity Revisited, Juni 2007

Nr. 63: Gundel, Sebastian: Declining Export Prices due to Increased Competition from NIC Evidence from Germany and the CEEC, April 2007

Nr. 62: Wilckens, Sebastian: Should WTO Dispute Settlement Be Subsidized?, April 2007

Nr. 61: Schöller, Deborah: Service Offshoring: A Challenge for Employment? Evidence from Germany, April 2007

Nr. 60: Janeba, Eckhard: Exports, Unemployment and the Welfare State, März 2007

Nr. 59: Lambsdoff, Johann Graf; Nell, Mathias: Fighting Corruption with Asymmetric Penalties and Leniency, Februar 2007

Nr. 58: Köller, Mareike: Unterschiedliche Direktinvestitionen in Irland - Eine theoriegestützte Analyse, August 2006

Nr. 57: Entorf, Horst; Lauk, Martina: Peer Effects, Social Multipliers and Migrants at School: An International Comparison, März 2007 (revidierte Fassung von Juli 2006)

Nr. 56: Görlich, Dennis; Trebesch, Christoph: Mass Migration and Seasonality Evidence on Moldova's Labour Exodus, Mai 2006

Nr. 55: Brandmeier, Michael: Reasons for Real Appreciation in Central Europe, Mai 2006

Nr. 54: Martínez-Zarzoso, Inmaculada; Nowak-Lehmann D., Felicitas: Is Distance a Good Proxy for Transport Costs? The Case of Competing Transport Modes, Mai 2006

Nr. 53: Ahrens, Joachim; Ohr, Renate; Zeddies, Götz: Enhanced Cooperation in an Enlarged EU, April 2006

Nr. 52: Stöwhase, Sven: Discrete Investment and Tax Competition when Firms shift Profits, April 2006

Nr. 51: Pelzer, Gesa: Darstellung der Beschäftigungseffekte von Exporten anhand einer InputOutput-Analyse, April 2006

Nr. 50: Elschner, Christina; Schwager, Robert: A Simulation Method to Measure the Tax Burden on Highly Skilled Manpower, März 2006

Nr. 49: Gaertner, Wulf; Xu, Yongsheng: A New Measure of the Standard of Living Based on Functionings, Oktober 2005

Nr. 48: Rincke, Johannes; Schwager, Robert: Skills, Social Mobility, and the Support for the Welfare State, September 2005 
Nr. 47: Bose, Niloy; Neumann, Rebecca: Explaining the Trend and the Diversity in the Evolution of the Stock Market, Juli 2005

Nr. 46: Kleinert, Jörn; Toubal, Farid: Gravity for FDI, Juni 2005

Nr. 45: Eckel, Carsten: International Trade, Flexible Manufacturing and Outsourcing, Mai 2005

Nr. 44: Hafner, Kurt A.: International Patent Pattern and Technology Diffusion, Mai 2005

Nr. 43: Nowak-Lehmann D., Felicitas; Herzer, Dierk; Martínez-Zarzoso, Inmaculada; Vollmer, Sebastian: Turkey and the Ankara Treaty of 1963: What can Trade Integration Do for Turkish Exports, Mai 2005

Nr. 42: Südekum, Jens: Does the Home Market Effect Arise in a Three-Country Model?, April 2005

Nr. 41: Carlberg, Michael: International Monetary Policy Coordination, April 2005

Nr. 40: Herzog, Bodo: Why do bigger countries have more problems with the Stability and Growth Pact?, April 2005

Nr. 39: Marouani, Mohamed A.: The Impact of the Mulitfiber Agreement Phaseout on Unemployment in Tunisia: a Prospective Dynamic Analysis, Januar 2005

Nr. 38: Bauer, Philipp; Riphahn, Regina T.: Heterogeneity in the Intergenerational Transmission of Educational Attainment: Evidence from Switzerland on Natives and Second Generation Immigrants, Januar 2005

Nr. 37: Büttner, Thiess: The Incentive Effect of Fiscal Equalization Transfers on Tax Policy, Januar 2005

Nr. 36: Feuerstein, Switgard; Grimm, Oliver: On the Credibility of Currency Boards, Oktober 2004

Nr. 35: Michaelis, Jochen; Minich, Heike: Inflationsdifferenzen im Euroraum - eine Bestandsaufnahme, Oktober 2004

Nr. 34: Neary, J. Peter: Cross-Border Mergers as Instruments of Comparative Advantage, Juli 2004

Nr. 33: Bjorvatn, Kjetil; Cappelen, Alexander W.: Globalisation, inequality and redistribution, Juli 2004

Nr. 32: Stremmel, Dennis: Geistige Eigentumsrechte im Welthandel: Stellt das TRIPs-Abkommen ein Protektionsinstrument der Industrieländer dar?, Juli 2004

Nr. 31: Hafner, Kurt: Industrial Agglomeration and Economic Development, Juni 2004

Nr. 30: Martinez-Zarzoso, Inmaculada; Nowak-Lehmann D., Felicitas: MERCOSUR-European Union Trade: How Important is EU Trade Liberalisation for MERCOSUR's Exports?, Juni 2004

Nr. 29: Birk, Angela; Michaelis, Jochen: Employment- and Growth Effects of Tax Reforms, Juni 2004

Nr. 28: Broll, Udo; Hansen, Sabine: Labour Demand and Exchange Rate Volatility, Juni 2004

Nr. 27: Bofinger, Peter; Mayer, Eric: Monetary and Fiscal Policy Interaction in the Euro Area with different assumptions on the Phillips curve, Juni 2004

Nr. 26: Torlak, Elvisa: Foreign Direct Investment, Technology Transfer and Productivity Growth in Transition Countries, Juni 2004

Nr. 25: Lorz, Oliver; Willmann, Gerald: On the Endogenous Allocation of Decision Powers in Federal Structures, Juni 2004

Nr. 24: Felbermayr, Gabriel J.: Specialization on a Technologically Stagnant Sector Need Not Be Bad for Growth, Juni 2004

Nr. 23: Carlberg, Michael: Monetary and Fiscal Policy Interactions in the Euro Area, Juni 2004

Nr. 22: Stähler, Frank: Market Entry and Foreign Direct Investment, Januar 2004

Nr. 21: Bester, Helmut; Konrad, Kai A.: Easy Targets and the Timing of Conflict, Dezember 2003 
Nr. 20: Eckel, Carsten: Does globalization lead to specialization, November 2003

Nr. 19: Ohr, Renate; Schmidt, André: Der Stabilitäts- und Wachstumspakt im Zielkonflikt zwischen fiskalischer Flexibilität und Glaubwürdigkeit: Ein Reform-ansatz unter Berücksichtigung konstitutionen- und institutionenökonomischer Aspekte, August 2003

Nr. 18: Ruehmann, Peter: Der deutsche Arbeitsmarkt: Fehlentwicklungen, Ursachen und Reformansätze, August 2003

Nr. 17: Suedekum, Jens: Subsidizing Education in the Economic Periphery: Another Pitfall of Regional Policies?, Januar 2003

Nr. 16: Graf Lambsdorff, Johann; Schinke, Michael: Non-Benevolent Central Banks, Dezember 2002

Nr. 15: Ziltener, Patrick: Wirtschaftliche Effekte des EU-Binnenmarktprogramms, November 2002

Nr. 14: Haufler, Andreas; Wooton, Ian: Regional Tax Coordination and Foreign Direct Investment, November 2001

Nr. 13: Schmidt, André: Non-Competition Factors in the European Competition Policy: The Necessity of Institutional Reforms, August 2001

Nr. 12: Lewis, Mervyn K.: Risk Management in Public Private Partnerships, Juni 2001

Nr. 11: Haaland, Jan I.; Wooton, Ian: Multinational Firms: Easy Come, Easy Go?, Mai 2001

Nr. 10: Wilkens, Ingrid: Flexibilisierung der Arbeit in den Niederlanden: Die Entwicklung atypischer Beschäftigung unter Berücksichtigung der Frauenerwerbstätigkeit, Januar 2001

Nr. 9: Graf Lambsdorff, Johann: How Corruption in Government Affects Public Welfare - A Review of Theories, Januar 2001

Nr. 8: Angermüller, Niels-Olaf: Währungskrisenmodelle aus neuerer Sicht, Oktober 2000

Nr. 7: $\quad$ Nowak-Lehmann, Felicitas: Was there Endogenous Growth in Chile (1960-1998)? A Test of the AK model, Oktober 2000

Nr. 6: Lunn, John; Steen, Todd P.: The Heterogeneity of Self-Employment: The Example of Asians in the United States, Juli 2000

Nr. 5: Güßefeldt, Jörg; Streit, Clemens: Disparitäten regionalwirtschaftlicher Entwicklung in der EU, Mai 2000

Nr. 4: Haufler, Andreas: Corporate Taxation, Profit Shifting, and the Efficiency of Public Input Provision, 1999

Nr. 3: Rühmann, Peter: European Monetary Union and National Labour Markets, September 1999

Nr. 2: Jarchow, Hans-Joachim: Eine offene Volkswirtschaft unter Berücksichtigung des Aktienmarktes, 1999

Nr. 1: Padoa-Schioppa, Tommaso: Reflections on the Globalization and the Europeanization of the Economy, Juni 1999

Alle bisher erschienenen Diskussionspapiere zum Download finden Sie im Internet unter: http://www.uni-goettingen.de/de/60920.html. 